Subscriber access provided by Universidad de Alicante

\title{
Perspective
}

\section{Electroactive biochar for large-scale environmental applications of microbial electrochemistry}

Andrea Schievano, Raúl Berenguer, Andrea Goglio, Stefano Bocchi, Stefania Marzorati, Laura Rago, Ricardo O. Louro, Catarina Paquete, and Abraham Esteve-Núñez

ACS Sustainable Chem. Eng., Just Accepted Manuscript • DOI: 10.1021/ acssuschemeng.9b04229 • Publication Date (Web): 11 Oct 2019

Downloaded from pubs.acs.org on October 15, 2019

\section{Just Accepted}

"Just Accepted" manuscripts have been peer-reviewed and accepted for publication. They are posted online prior to technical editing, formatting for publication and author proofing. The American Chemical Society provides "Just Accepted" as a service to the research community to expedite the dissemination of scientific material as soon as possible after acceptance. "Just Accepted" manuscripts appear in full in PDF format accompanied by an HTML abstract. "Just Accepted" manuscripts have been fully peer reviewed, but should not be considered the official version of record. They are citable by the Digital Object Identifier (DOI®). "Just Accepted" is an optional service offered to authors. Therefore, the "Just Accepted" Web site may not include all articles that will be published in the journal. After a manuscript is technically edited and formatted, it will be removed from the "Just Accepted" Web site and published as an ASAP article. Note that technical editing may introduce minor changes to the manuscript text and/or graphics which could affect content, and all legal disclaimers and ethical guidelines that apply to the journal pertain. ACS cannot be held responsible for errors or consequences arising from the use of information contained in these "Just Accepted" manuscripts. 


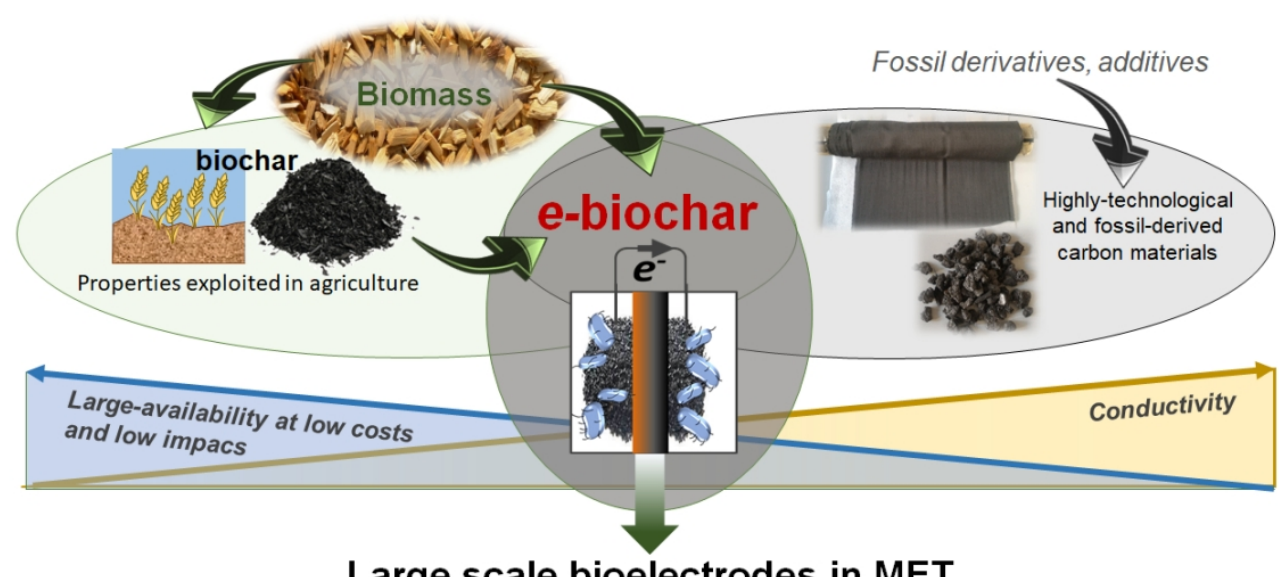

\section{Large scale bioelectrodes in MET}

Multiple conformations and configurations
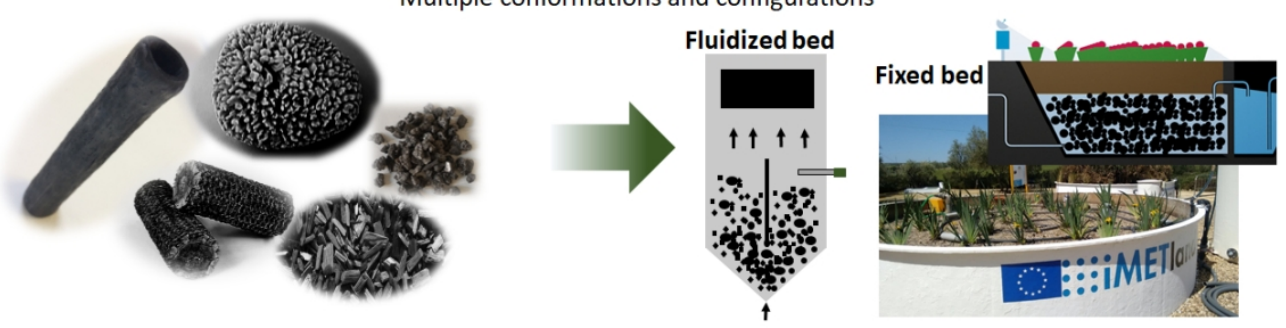

Abstract Art

$223 \times 165 \mathrm{~mm}(144 \times 144 \mathrm{DPI})$ 


\title{
Electroactive biochar for large-scale environmental applications of microbial electrochemistry
} Andrea Schievano*1, Raul Berenguer ${ }^{2,3}$, Andrea Goglio ${ }^{1}$, Stefano Bocchi ${ }^{1}$, Stefania Marzorati ${ }^{1}$, Laura Rago $^{1}$, Ricardo O. Louro ${ }^{4}$, Catarina M. Paquete ${ }^{4}$, Abraham Esteve-Núñez ${ }^{3,5}$

${ }^{1} e$-BioCenter - Department of Environmental Science and Policy (ESP), Università degli Studi di Milano, Via Celoria 2, 20133 Milan, Italy

${ }^{2}$ Instituto Universitario de Materiales, Departamento de Química Física, Universidad de Alicante UA, Apartado 99, 03080-Alicante, Spain

${ }^{3}$ IMDEA Water Institute, Av. Punto Com, 2, 28805 Alcalá de Henares, Madrid, Spain

${ }^{4}$ Instituto de Tecnologia Química e Biológica António Xavier da Universidade Nova de Lisboa, Av da República (EAN), 2780-157 Oeiras, Portugal

5 University of Alcalá, Department of Chemical Engineering, Ctra. Madrid-Barcelona, km. 33,6, 28871, Alcalá de Henares, Madrid, Spain

*Corresponding author; email: andrea.schievano@unimi.it

\begin{abstract}
Large-scale environmental applications of microbial electrochemical technologies (MET), such as wastewater treatment, bioremediation or soil improvement, would be more feasible if bioelectrodes could be fabricated with simpler materials. Biochar with potentially improved electroactive properties (e-biochar) can be an ideal candidate for this scope, being at the same time widely available, biocompatible and fully recyclable at end-of-life as soil amendment. Here we review the application of biochar to MET, to set benchmarks aimed at tuning the electroactive properties of such materials from the point of view of MET. The precursor biomass, thermochemical process conditions, and pre-, in-situ- and/or post-treatments should tailor optimized combinations of electrical conductivity, capacitance, superficial redox-active and electroactive functional groups, porosity distribution and capacity to host electroactive microbial communities. We also discuss methods to rigorously characterize $e$-biochar properties and the most relevant multidisciplinary research challenges towards its application in large-scale MET.
\end{abstract}

\section{Keywords}

e-biochar, microbial electrochemical technology, soil microbiology, bioremediation, electron transfer, bioelectrode; wastewater 


\section{Introduction: a new generation of bioelectrodes?}

Microbial electrochemical technologies (MET, see Nomenclature) are based on the capacity of certain microbes to use electrically conductive materials as electron acceptors or donors for their metabolism. Several different mechanisms involved in extracellular electron transfer (ET) to solid conductors have been demonstrated in a number of electroactive microorganisms (see Nomenclature) ${ }^{1}$. The interest in research on MET has grown exponentially and a variety of applications has been proposed. In over 15 years of laboratory- and pilot-scale studies, bioelectrodes (see Nomenclature) have been typically fabricated using 'technological' materials (e.g. carbon fibers, graphite, graphene, carbon nanotubes, precious metals such as titanium, platinum, etc.) ${ }^{2}$. At present, carbon materials represent the most widely used electrodic support, due to their excellent electrochemical properties and stability to corrosion. The most competitive include graphite-based rods, fiber brushes and granules, carbon-fiber cloths, carbon paper sheets, carbon felt and reticulated vitreous carbon ${ }^{3}$. Besides, often METs' architectures and materials have traced the technological features of typical engineered electrochemical cells, such as (abiotic) fuel cells or electrolysis cells. Such designs include plastic- or metal-based frames as support for electrodes or current collectors ${ }^{4-}$ ${ }^{8}$. Some examples of such electrodes were recently presented at the $\mathrm{m}^{2}$-scale ${ }^{9}$. However, when MET are envisioned for large-scale environmental applications (e.g. wastewater treatment, soil/water bioremediation, biomass processing, $\mathrm{CO}_{2}$ fixation, etc.), the use of such materials and architectures might be a substantial challenge, because of their high economic, environmental fabrication costs and low sustainability at end-of-life ${ }^{10}$.

In this article, we aim at pointing a spotlight on an emerging class of carbon materials for potential large-scale MET applications. The target materials should simultaneously be electroactive (see Nomenclature), to facilitate MET applications; available in large amounts, at relatively low costs and environmental impacts; and easily recyclable at end-of-life. Carbon materials with several electroactive properties can be also found in large quantities at potentially low costs (e.g. charcoal, black carbon, cokes and graphites). In MET, such materials have been extensively applied as coating layers on bioelectrodes to improve (bio-)electrochemical properties ${ }^{11}$. However, most of them are extracted from fossil reservoirs. More sustainable carbon materials, with similar and more versatile properties, can be produced by thermochemical conversions (see Nomenclature) of biomass and are generally referred to as biochar.

Biochar (see Nomenclature) has been extensively studied in the agricultural sciences framework as soil fertility improver and a way of sequestering chemically-stable carbon over long term ${ }^{12}$. Very rarely, electrochemical properties such as electrical conductivity and superficial electroactivity were considered in this framework. Commercial biochar has typically widely variable and relatively poor 
structural/mechanical properties (as compared to other carbons), as well as low electrical conductivity 13. This have generally restricted its technological applications as compared to more performing carbon-based materials.

In the MET field, electrical conductivity has been largely perceived as a key factor on performance of electrode materials. This might be probably due to the strong influence of the electrochemical science branch in this multidisciplinary field: several applications have been based on the possibility to harvest electrons through external circuits, just like in abiotic electrochemical cells (e.g. in microbial fuel cells, MFCs). In such applications, the role of biochar has remained marginal. However, METs embrace a much larger range of possible applications in the field of environmental biotechnology. For instance, one of the most fascinating recent findings was the possibility to enhance interspecies ET in soil microbial communities, by the presence of biochar ${ }^{14}$. In another study, biochar outperformed highly conductive carbon materials (graphite, coke) in stimulating extracellular ET and enhanced pollutants removal from wastewater in electroactive biofilters ${ }^{15}$. This happened because the superficial electroactivity played a major role, while electrical conductivity was sufficient to allow overall ET towards terminal electron acceptors ${ }^{15}$.

Here, we introduce the new concept of electroactive biochar (e-biochar), which constitutes a particular category of biochars, with a range of improved and tailored properties aimed at maximizing electrochemical interactions with microbes. Such materials would be ideal as bulk material for the fabrication of large-scale sustainable METs. So far, only a few studies have systematically focused on potential technological applications of such properties to fabricate large-scale bioelectrodes. In this paper, we set some benchmarks for future efforts in this promising research field.

\section{Biochar vs e-biochar}

Agriculture-derived biomass by-products and green waste can undergo thermochemical conversions, to yield bioenergy and biochar. Biochar has been largely studied as agricultural soil amendment, capable of favoring soils properties, acting as carbon sink over long term, stimulating soil microbial communities in several important soil processes ${ }^{16,17}$. Among agricultural scientists, biochar was considered as a relatively 'conductive' material, as compared to organic redox-active molecules (e.g. humic acids) ${ }^{18}$. Despite this, the potential impacts of biochar's electrochemical properties on microbial communities were rarely considered in this framework. More recently, some authors reported that the presence of biochar promotes interspecies ET in soils ${ }^{19-24}$. In a review, Yuan and colleagues 25 defined biochar as environmentally-sustainable electron donor/acceptor for biogeochemical redox reactions. Biochar acts as rechargeable reservoirs of bioavailable electrons, i.e. the so-called "geobatteries" 22,26. Functional groups can participate in reversible surface (interfacial) 
redox reactions with other ambient species, including electroactive microbial communities ${ }^{25}$. Besides, the carbon matrix, organized with variable graphitization degrees, can store, transport and exchange electrons, i.e. the 'geoconductor' mechanism ${ }^{26}$. While superficial electroactive functional groups play a key role in local ET ${ }^{27}$, extended conductive graphitic structures may enable long-range ET, facilitating external access to electron acceptors/donors. The combination of conductivity and ET capacity is generally referred to as 'electroactivity' ${ }^{26}$.

On the other side, material scientists and electrochemists have been considering biochar as an amorphous/low-crystalline material with interesting superficial ET properties, but poor electrical conductivity $\left(\sim 10^{-2}-10^{-4} \mathrm{~S} \mathrm{~cm}^{-1}\right.$, i.e. much lower than technological electrode materials), substantially unsuitable for fast-response abiotic electrochemical applications ${ }^{28}$.

Under the perspective of MET, however, the term 'electroactive' should be seen under a new light. Bioelectrodes are typically characterized by much slower ET rates and current densities than abiotic electrodes ${ }^{29}$. Therefore, high surface areas available for microbial EET, features stimulating extracellular ET, and sufficient conductivity may be needed for effective applications in METs, rather than materials with outperforming abiotic electrochemical properties. In this sense, biomass or conventional biochar can undergo thermochemical, chemical and structural treatments, for 'tuning' a wider spectrum of properties, that concur to harmonize the complex mechanisms involved in microbial EET, depending on the final MET application.

The obtained bulk material, 'e-biochar', is proposed as a new class of biochars with tailored conductivity and ET properties for specific METs application. Because widely available, biocompatible and fully recyclable at end-of-life as soil amendment, $e$-biochar is an ideal candidate to fabricate bioelectrodes for large scale METs applications, as compared to traditional 'technological' carbon conductors.

\section{e-biochar: fabrication of biochar with improved electrochemical properties}

To obtain ideal e-biochars, fabrication techniques should look at optimizing the main properties that influence electron transfer (ET), conduction and storage ${ }^{28}$. Under abiotic conditions, similarly to other carbon materials, biochar has been described to accept or donate electrons (irreversible superficial redox activity), reversibly transfer electrons (superficial electroactivity) or transport them within the material (electroconductivity) ${ }^{28}$. The porous texture and the available surface area at different pores dimensions have an important influence on these properties ${ }^{28}$. Finally, the capability to host and promote electroactive microbial communities over such surface is the key factor for ebiochar. Pores dimensions are also likely to determine the accessibility of surface area to direct contact with microbes or to biomolecules that promote EET ${ }^{30-32}$. 
The ideal e-biochar, depending on the application, could be rendered by an equilibrium of all these properties. This tuning is achieved by playing with the structural, textural and chemical nature of the precursor biomass, the conditions used during carbonization, additional chemical/physical treatments and the enrichment of microbial electroactive communities (Figure 1).

Redox-activity, electroactivity and conductivity are related with chemical and structural properties, which are modulated essentially by the temperature and pressures of preparation ${ }^{33}$. Biochar's conductivity is directly related to its structural (graphitic) order (Figure 1-n). Its structure may lie between amorphous (non-graphitic) natural organic molecules (humic/fulvic acids, biopolymers, etc.) and graphitized carbons (with variable 2D/3D crystalline order of polyaromatic layers) ${ }^{34}$. The longer the range of crystalline order, the more delocalized the $\pi$-electrons and, thus, the higher electrical conductivity. Higher aromatic content in the biomass may also lead to more conductive e-biochars ${ }^{35}$. Higher carbonization temperatures $\left(>600^{\circ} \mathrm{C}\right)$, slower heating rates and longer treatments (hours) promote structural order ${ }^{35,36}$ and, consequently, conductivity ${ }^{26}$. Some electron-donating O-, N- and metals functional groups may increase the conductivity too. By contrast, the presence of electrondemanding functional groups and increased porosity (rendering a larger concentration of textural defects) may decrease the conductivity of e-biochars. If normal biochar's conductivity falls typically in the range $10^{-2}-10^{-4} \mathrm{~S} / \mathrm{cm}$ (far from that of graphites $\sim 10-30 \mathrm{~S} / \mathrm{cm}$ ), e-biochar might find optimal values in between $\left(10^{-2}-10 \mathrm{~S} / \mathrm{cm}\right)$ (Table 1). However, deeper investigation is needed to define optimal conductivity ranges, depending on the target application, electrode configuration and dimensions.

Both quantity of available surface area and its quality (presence of electroactive functional groups and the capability of reversible binding/adsorption of ionic positive charges) strongly influence ET and the related phenomena (Figure 1-m), such as pseudocapacitance and double-layer capacitance ${ }^{28}$. Depending on the redox potential of superficial reversible redox-active groups and/or the aromatic rings, the material might show greater tendency to uptake/release electrons and transport through conductive graphitic structure (Figure 1-i) ${ }^{36-38}$. First, a suitable precursor may introduce a given proportion of O, N, P, S and metals on the final biochar ${ }^{39,40}$. Second, the choice of suitable heating conditions strongly affects the nature and concentration of superficial functional groups: at higher pyrolysis temperatures, both $\mathrm{O} / \mathrm{C}$ and $\mathrm{H} / \mathrm{C}$ ratios decrease ${ }^{36}$, as well as the proportion of less-stable O-functional groups in favor of more stable ones ${ }^{41}$. When prepared at lower temperatures $\left(<700^{\circ} \mathrm{C}\right)$, the ET in biochar is mainly mediated by surface functional groups (i.e. phenolic/quinoid groups) ${ }^{26,42}$. All the different functional groups are susceptible of exhibiting redox activity. Besides the wellknown phenolic/quinone couple, other have been demonstrated as abiotic electroactive functional groups: anhydride ${ }^{43}$, N-(pyridine/pyridinic) ${ }^{39}$ and P-groups ${ }^{44}$. 
Under abiotic conditions, an amount of $1.57 \mathrm{mmol}$ quinone $/ \mathrm{g}$ was found among the highest pseudocapacitive (electroactive) contributions ever reported in carbon materials ${ }^{45}$. Above $1200{ }^{\circ} \mathrm{C}$, most superficial functional groups are typically decomposed ${ }^{46}$. Another factor greatly affecting the redox- and electroactivity may be the presence of certain minerals (mineral oxides, silicates and salt phases) ${ }^{47}$. Special attention must be paid to the effects of some metallic species, particularly alkaline metals and other nutrients commonly present in biomass, which are well-known catalysts of the chemical activation of chars ${ }^{36}$.

The porous texture (see Nomenclature) is the last piece of this complex puzzle. Several literature reports revealed pore size distribution of extraordinary hierarchical architectures (Figure 2). Roughness and macroporosity mainly depend on the precursor (Figure 1a-b). Except for some thermoplastic biopolymers (which fluidize at certain temperature), the carbon-enriched material retains the initial characteristic shape (Table 1-c). Thus, some biochars can exhibit the vascular structure of preceding plant trunks/stems (Figure 2A-C). The meso-/microporosity inherently develops with increasing temperature by the loss of volatile matter, up to a maximum $\left(800-1000^{\circ} \mathrm{C}\right)$ 36,48 and then decreases due to solid reorganization. These features usually lead to surface areas in the 10-600 $\mathrm{m}^{2} / \mathrm{g}$ (Table 1).

Remarkably, a larger volume of micro-/mesopores reduces conductivity, but simultaneously provides a larger number of sites with distinct electroactive functional groups ${ }^{49}$. Meso- and micropores also determine the double-layer capacitance (electrostatic storage of charge by reversible adsorption of ions onto the surface, Figure 1-m). Since e-biochar particles must be globally neutral, the number of electrons exchanged by electroactive microorganisms are likely to be limited by the capability of the surface to compensate this negative charge. The effective adsorption of positive charges on a larger (microporous) surface area might therefore be a determining factor towards ET from biofilms. This hypothesis is in line with the geobattery mechanism ${ }^{22}$ and should be better investigated. An equilibrium between conductivity and superficial electroactive properties should be found, according to the target application, and deserve dedicated studies.

Finally, precursors (which can be either biomass or conventional agriculture-derived biochars, Figure 1-a) can be conformed into suitable conformations (pellets, monoliths, granules etc.) for specific applications (Figure 1-b). Several pre-, in-situ, and/or post-modification treatments (Figure 1-c) might tailor bulk e-biochars with optimized structural, textural and chemical features, similarly to activated carbons (Table 1). Surfaces can be chemically-/physically activated 40,50 . P-functional groups can be introduced by $\mathrm{H}_{3} \mathrm{PO}_{4}$-activation $37,44,46$ and various oxidative treatments may induce O-, N- and S- superficial functional groups ${ }^{41,51,52}$. Electrochemical post-treatments may be a green 
choice to incorporate electroactive phenolic/quinoid groups ${ }^{33}$. However, any additional treatment may increase the production costs and impacts of bulk e-biochar.

\section{Properties and characterization techniques to define $e$-biochar}

Structural, chemical, and textural properties should be thoroughly studied using a range of analytical techniques (Table 2). These properties strongly affect the abiotic redox-activity and electroactivity, features that have been often confused in the literature. Biochar's electroactivity is estimated as electron exchange capacity (EEC), i.e. the sum of the electron donating and accepting capacities (EDC, EAC) ${ }^{53}$. These properties are associated exclusively to reversible electroactive functional groups and often measured by mediated (indirect) electrochemical analysis 28,42,54. However, these methods detect also redox-active species that are irreversibly oxidized/reduced at biochar's surface 42,54. The characterization should be complemented by electrochemical techniques like CV and EIS

35: the electrochemically-active surface area (EAS) and the ion diffusion capability determine the reversible (abiotic) charge transfer with biochar surface. These properties are strongly influenced by the available micro- and meso-porous surface area. Remarkably, the electroactivity of quinoid-like groups, proposed to mediate in ET with bacteria, can be characterized by $\mathrm{CV}{ }^{26}$, and the involved charge may be related to their number and accessibility of these groups, the conductivity, etc.

The actual capability of the material to promote ET in microbial reactions completes the definition of $e$-biochar. The $e$-accepting/donating capacity of $e$-biochar in MET is proportional to the abundance and diversity of electroactive biofilm communities grown on the solid surface. As the ultimate charge transfer depends on microbial EET kinetics, which are typically much slower than in abiotic ET, electrochemical techniques are often adapted to such conditions ${ }^{55}$. The morphology of biofilms can be revealed by several microscope techniques, coupled to selective probes. Microbial electroactive communities can also be investigated by molecular, culture-dependent analyses and microscopic techniques (Table 2).

\section{State of the art of biochar in MET}

Little is rigorously proven about the possible electrochemical interactions between microorganisms and biochar. In the agricultural and soil science framework, positive effects of biochar on soil microbial pool have been largely reported ${ }^{17}$. However, electrochemical aspects were rarely taken into account. Only more recently, the emerging scientific community of microbial electrochemistry published a relatively small number of studies on the behavior of biochar as electrode interface in specific MET (Table 1). Some authors used biochar on MET electrodes, but limited the focus to 
particular electrocatalytic properties of the material on abiotic electrodes (Table 1-a). Several other authors reported that the presence of biochar on bioelectrodes enhanced redox reactions towards metals or organic compounds, by enriching the biofilm community with electroactive microbial species $20,21,23,24,56,57$. Remarkably, biochar was demonstrated to act as promoter of direct interspecies ET for different syntrophic associations of microorganisms, thanks to its electrical conductivity and stimulating capacity of EET by pili or other direct membrane mediators ${ }^{14}$. In this study, microbial co-cultures did not need to form aggregates, suggesting that the cells were electrically connected through the biochar, which permitted EET. Besides, the addition of biochar particles in anaerobic fermenters was found to increase overall electrical conductivity in the bulk liquid and facilitate EET, between both fermentative and methanogenic communities ${ }^{58-62}$. Interestingly, SEM images of the biofilm showed that both microbial cells and high-density structure of extracellular polymeric substances (EPS) were increasingly denser in the vicinity of biochar particles ${ }^{58}$.

In these studies, however, several reasons have often led to uncertain conclusions. Biochars are complex materials showing inter-related properties, affecting extracellular ET in different ways. There is a lack of systematic studies analyzing the influence of only one property, disregarding others. Tailoring specific properties, without affecting the others, is difficult; in most works the characterization of biochar was incomplete; both surface chemistry and porous texture of biochar were insufficiently considered for their influence in extracellular ET (Table 1).

The accessibility to the electrochemically-active surface area (EAS) includes more aspects than in abiotic systems, implying the capability to host microbes (Figure 1-h) and/or promote diffusion of many different primary agents, i.e. ions, electrons, redox mediators, electron shuttles (see Nomenclature) and increase hydrophilic properties of the material. In e-biochar-based bioelectrodes, surface area and pore volume distribution (Figure 2) likely play a relevant role for reasons other than affecting conductivity and superficial redox reactions. Suitable pore textures are essential to host microbial communities and promote biofilm growth ${ }^{63}$. Also, EET reactions depend on the accessibility of surface area to the primary agents of redox reactions, including microbial cells, molecular electron shuttles, soluble carbon sources and dissolved ions.

In particular, surface roughness and macroporous surface area (Figure 1-j) strongly influence the access of microbes to surface ${ }^{64}$ and biofilm anchorage ${ }^{65,66}$. This aspect is well known and carbon powders are widely used to increase the surface of plain carbon-cloth bioelectrodes and improve their bioelectrochemical performances ${ }^{67}$. Although, most studies on carbon-based bioelectrodes lack of data regarding architectural and dimensional features at macroporous scales, focusing only on mesoand micro-pores ${ }^{2}$. The surface area of meso-pores (Figure 1-I) is inaccessible to microbial cells (< $50 \mathrm{~nm}$, Figure 2) and eventually available only to molecular electron shuttles (Figure 1-h). In fact, 
EET processes performed by electroactive microorganisms are based either on direct contact with the cell, or through redox-active molecules, that interact with the components of the respiratory redoxchain and diffuse in the outer medium ${ }^{27}$ (Figure 1-h). Up to date, four types of cell-surface redox proteins (see Nomenclature) were identified to be responsible for ET across the cell-surface of electroactive organisms. Among these, cell-surface exposed cytochromes were found as principal cellular components in interacting with solid conductors and with different electron shuttles ${ }^{68}$. Redox proteins (particularly multiheme cytochromes) form conductive ET chains that allows the exchange of electrons with solid electron donor or acceptors outside of the cell ${ }^{30}$. Furthermore, numerous electroactive microorganisms may employ cellular structures, such as nanowires or pili to improve EET ${ }^{69}$. Recently, it has also been demonstrated that EPS also facilitate EET ${ }^{70}$.

The accessibility of such molecules to all potential meso-, micro- and ultramicro-porous surface area might greatly affect the overall ET. Smaller pores are likely to act as cut-off barriers for such biomolecules, according to their molecular dimension and architecture. These aspects should particularly be focus of deeper insights.

\section{Large scale bioelectrodes based on e-biochar?}

Bioelectrodes architectures generally include different features, such as defined structural shapes (e.g. plain, granular, cylindrical, sponge-like), porous separation layers (e.g. air-water interface for airexposed cathodes ${ }^{71,72}$ ), and current collection frameworks ${ }^{2}$. Many carbon-based 'technological' materials (e.g. carbon fibers, cloths and rods, graphite) have excellent structural and conductive properties, but generally very low EAS ${ }^{73}$. Therefore, many of them can barely act as current collectors, rather than efficient bioelectrodes ${ }^{72}$. On the other side, activated carbon powders, carbon nanotubes and other nanomaterials with high surface areas were largely employed to increase biofilm adhesion, improve EAS and/or abiotic electrocatalytic properties ${ }^{2}$. To this end, polymeric binders, resins and other adhesives have been extensively employed to create layers of these powders on current collectors in lab-scale MET applications ${ }^{2,72}$.

Lab-scale studies have seldom taken into account the real applicability at large scales of intensivelymanufactured materials (carbon fibers, cloths, meshes, felts), non-renewable or engineered carbons (graphites, charcoal, cokes, activated carbon powders, nanotubes) and non-biocompatible additives (PTFE, Nafion ${ }^{\circledR}$, polyvinyl alcohol and other binders) ${ }^{72}$. Very few authors have been mentioning the economic costs of such materials ${ }^{74,75}$ and even less have assessed their life cycle and environmental compatibility ${ }^{76}$, envisioning large scales manufacturing ${ }^{10}$.

Optimized e-biochar have potential of being more efficient and versatile (with customized fabrication design and properties), including the characteristics of both structural features of a current collector 
(defined conformation, mechanical rigidity, conductivity) and high EAS. This idea is supported by a reasonable number of reports, where electrodes designs are based on biochar monoliths with selfsupported 3-Dimensional structures (Table 1-c). Good examples are binder-free air-cathodes made of sintered activated carbon powders, which were found to be inexpensive and easily mass manufactured ${ }^{72}$. Other authors fabricated bioelectrodes via ligno-cellulosic biomass carbonization, while preserving the original 3-D shape. Bioanodes were obtained from carbonized plant stems (kenaf and bamboo), corn cobs, marine loofah sponges, king/wild mushrooms ${ }^{64,77-79}$. Rigid air-breathing biocathodes were obtained from Giant cane stems, which maintained their original cylindrical shape and simultaneously acted as microporous air-water separators ${ }^{71,80}$.

Bioelectrodes configurations even closer to scaled-up MET applications were also proposed, even if in some cases the employed carbon materials (e.g. activated carbon granules) were from origins other than biomass (Table 1-d). Fluid-like bioelectrodes made of floating carbon particles are very promising configurations ${ }^{81}$. Electroconductive granules are fluidized in a bioreactor acting as "planktonic" electrodes supporting microbial electroactivity ${ }^{82}$. Electrons accumulate on the material and are discharged to a collector by periodic contact. The potentials of this concept is currently under investigation at Bioe group (University of Alcalá, Spain).

Until today, most of the experiments on biochar have been run using regular electrochemical cells configurations, i.e. with well-defined anodic and cathodic electrode surfaces, with uniform electrochemical potential. However, we envisage the most interesting applications of $e$-biochar with not well-defined anodic or cathodic electrode surfaces. Every single niche created by electroactive communities at the surface of biochar might behave like an anode or a cathode, depending on the redox conditions in the electrolyte as well as on the surface of conductive portion of biochar. Granular carbons of macroscopic size and sufficient mechanical rigidity (diameters in the range of 5 $-20 \mathrm{~mm}$ ) were also the base of fixed- or packed-bed bioelectrodes (either anodes or cathodes), for different purposes ${ }^{83-85}$. This design has been applied to probably the largest-scale application of MET, which merges the use of electroactive material with the concept of constructed wetland. The result is the so-called 'METland' concept where the classical bed biofilter made of inert material can be substituted by electroconductive material ${ }^{86}$. Based on this concept, a 20- $\mathrm{m}^{2}$ METland made of ebiochar was constructed for treating around $7 \mathrm{~m}^{3} /$ day of urban wastewater. The e-biochar acts as electroconductive bed for electroactive biofilm and helps in avoiding electron acceptor limitations for bacteria. The final outcome is a stimulation of the ET mechanism that resulted in a large enhancement of the biodegradation rates for organic pollutants in the wastewater with no energy cost and under extremely low growth yield ${ }^{86}$. 
METland biofilters made of e-biochar have been also used at large scale for enhancing anaerobic treatment in a real-scale wastewater treatment plant (serving a community of around 200 people) recently constructed by the startup company METfilter at Otos (Murcia, Spain). Interestingly, in METlands e-biochar was considerably more efficient for wastewater treatment than more conductive materials (coke and graphite) ${ }^{87}$. Higher performances were observed under a wide range of operational conditions, including polarization at 0.4 and $0.6 \mathrm{~V}$ (vs. $\mathrm{Ag} / \mathrm{AgCl} / \mathrm{Cl}^{-}$ref.) ${ }^{87}$. Higher working potentials showed higher currents for graphite, but overall lower COD removal efficiency, as compared to e-biochar. Hence, larger EAS, hierarchical pore architecture and richer surface chemistry (including phenol and quinones) might dominate over conductivity in some systems. Such aspects deserve deeper investigation.

\section{Outlook and future challenges}

e-biochar is an intriguing candidate to realize the ambitious promises of large-scale MET applications. However, many aspects remain definitely open, due a substantial lack of comprehensive and multidisciplinary approaches in the existing literature reports. Both fundamental studies and applied research are still needed, involving a wide variety of cross-disciplines. A lot of work has still to be done to identify and obtain the best characteristics of the material according to different targets. To achieve this goal, all available knowledge on biochar involving surface material chemistry, thermochemical processing, nanotechnology and abiotic electrochemistry, should be strictly complemented with approaches coming from bioelectrochemistry, molecular studies on ET, microbial metabolism and microbial biofilm ecology. In parallel, environmental and bioprocess engineering should accompany basic studies to foresee the viability of potential applications at certain scales. Up to date, the large majority of studies lacks a vision for scalable bioelectrodes configurations.

In spite of the attractive "circular economy" concept (Figure 1), both economic and environmental sustainability of $e$-biochar production at target scales should be analyzed by proper tools, such as exhaustive Life Cycle Assessment. For example, hydrothermal carbonization (HTC) might bring some advantages on conventional pyrolysis, excluding energy-intensive drying before or during the process. This opens up the field to several alternative sources: wet animal manures, human waste, sewage sludges, municipal solid waste (MSW), as well as aquaculture and algal residues ${ }^{88}$. Finally, soil science and agronomy should also be involved both at the beginning and end of the chain. Sustainable biomass supply, including agricultural and agro-industry residues and green waste, is the first key element towards the sustainability of the whole concept. Simultaneously, studies should assess the possibility of fully recycle e-biochar after bielectrodes working life, as amendment for 
agricultural soil application in view of long-term carbon storage as strategy to mitigate climate change 12 .

\section{Acknowledgements}

This work has been financed by the Italian Ministry of University and Research (MIUR), within the SIR2014 Grant, project RBSI14JKU3. Dr. R. Berenguer also thanks the Spanish Ministerio de Economía y Competitividad and FEDER funds (RYC-2017-23618) for financial support. 


\section{Nomenclature}

Biochar: a chemically-stable form of carbon (charcoal) derived from thermochemical conversions of biomass.

Bioelectrode: electrodes where the electrocatalysis is driven by living microbes.

Cell-surface redox proteins: Proteins present at the cell-surface of organisms, containing one or several redox groups, responsible to transfer electrons with electrodes, soluble electron shuttles, or insoluble metals. Examples of these proteins are the outer-membrane cytochromes, including MtrC and OmcA from Shewanella oneidensis $\mathrm{MR}-1, \mathrm{OmcS}, \mathrm{OmcB}, \mathrm{OmcF}$ and $\mathrm{OmcZ}$ from Geobacter sulfurreduces, PioA from Rhodopseudomonas palustris, among others ${ }^{68}$.

Electron shuttles: Mobile compounds produced by microorganisms that can assist EET, including quinones, flavins, humic substrances and phenazines.

e-pili and nanowires: Electrically-conductive appendages and outer-membrane extensions described in Gram-negative bacteria that assist in the process of EET.

Electron transfer (ET): chemical/biochemical processes driving the exchange of electrons by redox and electroconductive mechanisms.

Extracellular electron transfer: The process by which microorganisms exchange electrons across the cell surface for the reduction/oxidation of extracellular compounds. Metal-reducing organisms use EET to respire metal oxides/hydroxides, while others to exchange electrons with solid electrodes. Electroactive microorganisms: Microorganisms that are able to exchange electrons with an electrochemically-active surface such as an electrode.

Electroactive: a material/surface with chemical and textural properties allowing efficient ET from/to external sources/sinks of electrons.

Microbial electrochemical technologies (METs). Electrochemical devices where ET from/to electrodes is mediated by living microbial cells. Several applications (e.g. microbial fuel, electrolysis, electrofermentation and electrosynthesis cells) are used to enhance a range of bioprocesses of environmental interest (e.g. wastewater treatment, water desalination, nutrients recovery, soil bioremediation, environmental sensing, biomass processing, $\mathrm{CO}_{2}$ fixation towards bio-molecules and biofuels production).

Porous texture: Macropores: pores with diameter (d) more than $50 \mathrm{~nm}$; Mesopores: pores with 2 $<\mathrm{d}<50 \mathrm{~nm}$; Micropores: pores with $\mathrm{d}<2 \mathrm{~nm}$; Ultra-micropores: pores with $\mathrm{d}<0.7 \mathrm{~nm}$.

Thermochemical conversions: Biochars are produced either by pyrolysis or hydrothermal carbonization (HTC). Both processes involve thermochemical decomposition of biomass in absence of stoichiometric oxygen, leading to a progressive increase in C-content (carbonization) ${ }^{34}$. Both processes are esoergonic, with the production of heat and reduced volatile molecules $\left(\mathrm{H}_{2}, \mathrm{CO}\right.$, etc.). 
Pyrolysis is carried out under reducing atmosphere (at $>200^{\circ} \mathrm{C}$ ), while HTC (also called wet pyrolysis) under autogenous pressure $(<20 \mathrm{bar})$ and temperature $\left(<350^{\circ} \mathrm{C}\right)$ in subcritical water. The product is known as hydrochar 34,88 . Typical solid yields of (slow or intermediate) pyrolysis are $20-40 \%$, whereas 50-80\% for HTC in relatively short times $(1-24 \mathrm{~h})^{88}$. 
Table 1 - Studies reporting properties of e-biochars, fabrication techniques, observed effects on microbial communities, observed ET mechanisms.

\begin{tabular}{|c|c|c|c|c|c|c|c|c|}
\hline Precursor Feedstock & $\begin{array}{l}\text { Pyrolysis conditions } \\
\text { and treatments }\end{array}$ & $\begin{array}{l}\text { Particle size or } \\
\text { geometrical shape }\end{array}$ & $\begin{array}{l}\text { BET* } \\
\text { Surface } \\
\text { Area } \\
/ \mathbf{m}^{2} \mathbf{g}^{-1} \\
\end{array}$ & $\begin{array}{l}\text { Porosity } \\
\text { range }\end{array}$ & $\begin{array}{l}\text { Electrical } \\
\text { conductivity } \\
/ \mathbf{m S ~ c m}^{-1}\end{array}$ & $\begin{array}{l}\text { Surface } \\
\text { heteroatoms } \\
\text { / functional } \\
\text { groups }\end{array}$ & $\begin{array}{l}\text { Function in electrodes, observed effects and main } \\
\text { electrochemical parameters }\end{array}$ & Ref. \\
\hline \multicolumn{9}{|c|}{ a. Studied in abiotic electrodes } \\
\hline Pomelo peel & $1000^{\circ} \mathrm{C}$ & n.r.* & 622.2 & $\begin{array}{l}63 \% \text { micro, } \\
36 \% \text { meso }\end{array}$ & n.r. & $\mathrm{Fe}, \mathrm{N}$ & $\begin{array}{l}\text { Studied as coating for abiotic ORR* electrocatalysis: } \\
j=1.7 \mathrm{~mA} \mathrm{~cm}-2 ; U=0.1997 \pm 0.0013 \mathrm{~mW} \mathrm{~cm}{ }^{-2}\end{array}$ & 89 \\
\hline Dewatered sewage sludge & $800^{\circ} \mathrm{C}$ & n.r. & 265.05 & Mesopores & n.r. & $\mathrm{N}, \mathrm{S}, \mathrm{Fe}$ & $\begin{array}{l}\text { OER* and ORR* electrocatalysis }^{*} \\
j=5.65 \mathrm{~mA} \mathrm{~cm}-2 ; U=\text { n.r. }\end{array}$ & 90 \\
\hline Cellulose & $250-500^{\circ} \mathrm{C}$ & $0.8-2 \mathrm{~mm}$ & $199-557$ & Mesopores & n.r. & $\mathrm{N}, \mathrm{P}$ & $\begin{array}{l}\text { Catalyst support for abiotic } \mathrm{MeOH} \text { oxidation } \\
j=\text { n.r.; } U=\text { n.r. }\end{array}$ & 91 \\
\hline Coconut shell & $800^{\circ} \mathrm{C}$ & $\begin{array}{l}\text { Carbon paste electrode } \\
\text { (mixed with spectro grade } \\
\text { paraffin wax) }\end{array}$ & 2536 & Micropores & n.r. & n.r. & $\begin{array}{l}\text { Photocatalytic hydrogen production } \\
j=\text { n.r.; } U=\text { n.r. }\end{array}$ & 92 \\
\hline Cotton microfiber & $700-850^{\circ} \mathrm{C}$ & n.r. & 912.1 & Mesopores & n.r. & $\mathrm{N}$ & $\begin{array}{l}\text { ORR* abiotic electrocatalysis } \\
j=5 \mathrm{~mA} \mathrm{~cm}-2 ; U=\text { n.r. }\end{array}$ & 93 \\
\hline Sawdust and sugarcane straw & $800^{\circ} \mathrm{C}$ & n.r. & 590 & Micropores & n.r. & n.r. & $\begin{array}{l}\text { Abiotic catalyst for sulfide oxidation } \\
j=\text { n.r.; } U=\text { n.r. }\end{array}$ & 94 \\
\hline \multicolumn{9}{|c|}{ b. Studied in MET at laboratory scale } \\
\hline Pine & $\begin{array}{l}700^{\circ} \mathrm{C} \text { for } 30 \mathrm{sec} \& \\
500^{\circ} \mathrm{C} \text { for } 15 \mathrm{~min}\end{array}$ & $\leq 0.4 \mathrm{~mm}$ & 15 & n.a & 4.4 & n.r. & $\begin{array}{l}\text { Biochar promoted interspecies ET in co-cultures of Geobacter } \\
\text { metallireducens with Methanosarcina barkeri } \\
j=\text { n.r.; } U=\text { n.r. }\end{array}$ & 14 \\
\hline Wood chip & $620^{\circ} \mathrm{C}$ & $\begin{array}{l}0.1-0.3 \mu \mathrm{m} \text { and a } \\
\text { significant fraction of } \\
3-30 \mu \mathrm{m}\end{array}$ & 341 & n.a & 49.7 & $\mathrm{~N}, \mathrm{Fe}$ & $\begin{array}{l}\text { Biochar improved the microbial reduction of the } \mathrm{Fe}(\mathrm{III}) \text { by } \\
\text { Shewanella oneidensis MR-1 } \\
j=\text { n.r.; } U=\text { n.r. }\end{array}$ & 20 \\
\hline Rape-straw & $\begin{array}{l}350^{\circ} \mathrm{C}, 20^{\circ} \mathrm{C} \min ^{-1} \\
\text { held constant for } 4 \mathrm{~h}\end{array}$ & $0.165-\mathrm{mm}$ & 2.12 & n.r. & n.r. & n.r. & $\begin{array}{l}\text { Biochar accelerated the reductive dechlorination of PCP by } \\
\text { stimulated the dechlorinating bacteria and Fe(III)-reducing bacteria } \\
j=\text { n.r.; } U=\text { n.r. }\end{array}$ & 95 \\
\hline Rice straw & $\begin{array}{l}\text { increase at } 20^{\circ} \mathrm{C} \mathrm{min}^{-1} \\
\text { up to } 900^{\circ} \mathrm{C} \text { for } 1 \mathrm{~h}\end{array}$ & $0.15 \mathrm{~mm}$ & 10.85 & n.r. & 2.4 & n.r. & $\begin{array}{l}\text { Biochar worked as electron mediators for the dechlorination of PCP } \\
j=\text { n.r.; } U=\text { n.r. }\end{array}$ & 21 \\
\hline Sieving residues & $550^{\circ} \mathrm{C}$ for $2 \mathrm{~h}$ & n.r. & 193.9 & n.r. & n.r. & n.r. & $\begin{array}{l}\text { Biochar influenced the speciation of metals by increasing the } \\
\text { relative abundance of } \mathrm{As}(\mathrm{V})-\mathrm{Fe}(\mathrm{III}) \text {-reducing bacteria (mostly } \\
\text { Geobacter, Anaeromyxobacter, Desulfosporosinus and Pedobacter) } \\
j=\text { n.r.; } U=\text { n.r. }\end{array}$ & 24 \\
\hline Mature coconut shell & $900^{\circ} \mathrm{C}$ for $1.5 \mathrm{~h}$ & $0.3 \mathrm{~mm}$ & n.r. & n.r. & 2.6 & n.r. & $\begin{array}{l}\text { Biochar improved sediment MFC power generation and TOC } \\
\text { removal rate by enriching the Firmicutes (mostly Fusibacter sp.) } \\
j=0.045 \mathrm{~mA} \mathrm{~cm}-2 ; U=0.0053 \mathrm{~mW} \mathrm{~cm}{ }^{-2}\end{array}$ & 56 \\
\hline Activated sludge & $\begin{array}{l}\text { increase at } 10^{\circ} \mathrm{C} \mathrm{min}^{-1} \\
\text { up to } 500^{\circ} \mathrm{C}\end{array}$ & $0.15 \mathrm{~mm}$ & n.r. & n.r. & n.r. & n.r. & $\begin{array}{l}\text { Biochar improved bioleaching efficiency of metals by regulating } \\
\text { the ratio of Alicyclobacillus spp. and Sulfobacillus spp. } \\
j=\text { n.r.; } U=\text { n.r }\end{array}$ & 96 \\
\hline
\end{tabular}




\begin{tabular}{|c|c|c|c|c|c|c|c|c|}
\hline Fruitwoods & $800-900^{\circ} \mathrm{C}$ & $\begin{array}{l}2-5 \mathrm{~mm}, 0.5-1 \mathrm{~mm} \text { and } \\
75-150 \mu \mathrm{m}\end{array}$ & n.r. & n.r. & n.r. & n.r. & $\begin{array}{l}\text { Biochar increased the resistance to ammonium and substrate high } \\
\text { concentrations by enriching Methanosaeta and then Methanosarcina } \\
j=\text { n.r.; } U=\text { n.r. }\end{array}$ & 60 \\
\hline $\begin{array}{l}\text { Rice-straw treated with } 3.2 \mathrm{~g} \\
\mathrm{FeCl}_{3}: 100 \mathrm{~g}\end{array}$ & $500^{\circ} \mathrm{C}$ for $2 \mathrm{~h}$ & $0.15 \mathrm{~mm}$ & 5.48 & Mesopores & n.r. & n.r. & $\begin{array}{l}\text { Biochar improved methane production due to selective enrichment } \\
\text { of electroactive bacteria participating in anaerobic digestion } \\
j=\text { n.r.; } U=\text { n.r. }\end{array}$ & 59 \\
\hline Pine chips & $800-1000^{\circ} \mathrm{C}$ for $8 \mathrm{~h}$ & $0.5-1.0 \mathrm{~mm}$ & 8.92 & n.r. & n.r. & n.r. & $\begin{array}{l}\text { Biochar enhanced caproate and caprylate production via chain } \\
\text { elongation } \\
j=\text { n.r.; } U=\text { n.r. }\end{array}$ & 58 \\
\hline Rice straw & $\begin{array}{l}5^{\circ} \mathrm{C} \min ^{-1} \text { up to } \\
\text { maximum } \mathrm{T}^{\mathrm{o}} \text { for } 2 \mathrm{~h}: \\
300^{\circ} \mathrm{C}, 800{ }^{\circ} \mathrm{C}\end{array}$ & $0.15 \mathrm{~mm}$ & $\begin{array}{l}2.6 \\
205\end{array}$ & n.r. & $\begin{array}{l}8.4 \\
20.4\end{array}$ & n.r. & $\begin{array}{l}300^{\circ} \mathrm{C} \text {-biochar reduced } \mathrm{NO}_{3}-\text { faster by the enrichment of the } \\
\text { nitrate-reducing bacteria. } 800^{\circ} \mathrm{C} \text {-biochar decreased denitrification } \\
\text { rate and promoted } \mathrm{N}_{2} \mathrm{O} \text { reduction } \\
j=\text { n.r.; } U=\text { n.r. }\end{array}$ & 97 \\
\hline Pine wood lumber & $1000^{\circ} \mathrm{C}$ & Fine frit glass filter funnel & 183.0 & $\begin{array}{l}82 \% \\
\text { Micropores }\end{array}$ & n.r. & $\begin{array}{l}\text { Traces of } \\
\text { metals }\end{array}$ & $\begin{array}{l}\text { Electrocatalytic layer on a carbon cloth support for air-breathing } \\
\text { cathode in MFCs } \\
j=0.9 \mathrm{~mA} \mathrm{~cm}-2 ; U=0.015 \mathrm{~mW} \mathrm{~cm}{ }^{-2}\end{array}$ & 98 \\
\hline Bananas & $550-900^{\circ} \mathrm{C}$ & Ground to powder & $\begin{array}{l}105.2- \\
172.3\end{array}$ & n.r. & n.r. & $\mathrm{N}$ & $\begin{array}{l}\text { Electrocatalytic layer on a carbon cloth support for air-breathing } \\
\text { cathode in MFCs } \\
j=-0.79 \text { for } 550^{\circ} \mathrm{C}-\text { biochar; } j=-3.5 \mathrm{~mA} \mathrm{~cm}-2 \text { for } 900^{\circ} \mathrm{C}-\text { biochar at } \\
-0.8 \text { V. } U=0.05 \mathrm{~mW} \mathrm{~cm}{ }^{-2} \text { for } 900^{\circ} \mathrm{C}-\text { biochar as cathode }\end{array}$ & 99 \\
\hline Corncob & $\begin{array}{l}250,350,450,550 \\
650,750^{\circ} \mathrm{C} \text { for } 2 \mathrm{~h}\end{array}$ & Ground to powder & n.r. & n.r. & n.r. & n.r. & $\begin{array}{l}\text { Used as a layer on a carbon cloth MFC cathode for abiotic ORR* } \\
j=9 \mathrm{~mA} \mathrm{~cm}^{-2} ; U=458.85 \mathrm{~mW} \mathrm{~m}^{-3}\end{array}$ & 100 \\
\hline \multicolumn{9}{|c|}{ c. Self-standing 3D shaped e-biochar bioelectrodes } \\
\hline $\begin{array}{l}\text { Pinewood sawdust pellets and } \\
\text { chips }\end{array}$ & $1000^{\circ} \mathrm{C}$ & $26-700 \mathrm{~mm}^{3}$ & 0.04 & $\begin{array}{l}\text { Small } \\
\text { mesopores }\end{array}$ & $16-35$ & n.r. & $\begin{array}{l}\text { Granular bioanodes in MFCs } \\
j=\text { n.r. ; } U=457 \mathrm{~mW} \mathrm{~m}^{-2} \text { for forestry residue and } U=532 \mathrm{~mW} \mathrm{~m}^{-2} \\
\text { for compressed milling residue }\end{array}$ & 32 \\
\hline $\begin{array}{l}\text { Giant cane (Arundo donax L.) } \\
\text { stalks }\end{array}$ & $900{ }^{\circ} \mathrm{C}$ & $\begin{array}{l}\text { Natural cylindrical shape } \\
(10 \mathrm{~mm} \text { diameter, } 10-20 \\
\mathrm{cm} \text { length) }\end{array}$ & 114 & Micropores & 11 & $\mathrm{~N}, \mathrm{P}$ & $\begin{array}{l}\text { Air-breathing biocathodes in METs, acting as self-structured air- } \\
\text { water porous interface, with cylindrical shape } \\
j=130 \mathrm{~mA} \mathrm{~m}^{-2} ; U=40 \mathrm{~mW} \mathrm{~m}^{-2}\end{array}$ & 71,80 \\
\hline Kenaf (Hibiscus cannabinus) & $1000^{\circ} \mathrm{C}$ & $\begin{array}{l}\text { Natural cylindrical shape } \\
4 \mathrm{~mm} / 10 \mathrm{~mm} \text { inner/outer } \\
\text { diameters }\end{array}$ & n.r. & $\begin{array}{l}\text { Macro- } \\
\text { channels of } \\
50-60 \mu \mathrm{m}\end{array}$ & n.r. & n.r. & $\begin{array}{l}\text { Studied as bioanodes } \\
j=32.5 \mathrm{~A} \mathrm{~m}^{-2} . ; U=\text { n.r. }\end{array}$ & 64 \\
\hline Bamboo & $1000^{\circ} \mathrm{C}$ & $\begin{array}{l}\text { Tubes with inner } \\
\text { diameter: } 1 \mathrm{~mm}, 1.5 \mathrm{~mm} \text {, } \\
2 \mathrm{~mm} \text { and } 3 \mathrm{~mm}\end{array}$ & n.r. & n.r. & n.r. & n.r. & 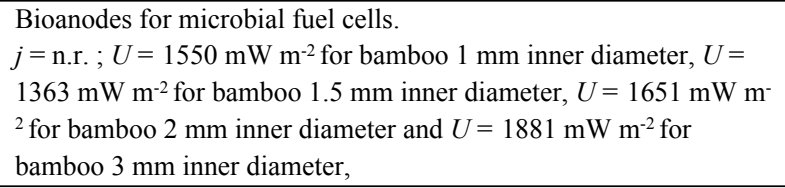 & 79 \\
\hline $\begin{array}{l}\text { King mushroom, wild } \\
\text { mushroom and corn stem }\end{array}$ & $1000^{\circ} \mathrm{C}$ & Sponge-like architecture & n.r. & $\begin{array}{l}\text { Macroporous } \\
\text { architecture }\end{array}$ & n.r. & n.r. & $\begin{array}{l}\text { Anodes for microbial fuel cells. } \\
j=3.12 \mathrm{~mA} \mathrm{~cm}^{-2} . ; U=\text { n.r. }\end{array}$ & 101 \\
\hline
\end{tabular}




\begin{tabular}{|c|c|c|c|c|c|c|c|c|}
\hline Natural Loofah Sponge & $900^{\circ} \mathrm{C}$ & Sponge-like architecture & $445-504$ & $\begin{array}{l}\text { Macroporous } \\
\text { architecture }\end{array}$ & n.r. & $\mathrm{N}$ & $\begin{array}{l}\text { Anodes for microbial fuel cells. } \\
j=5.6 \mathrm{~mA} \mathrm{~m}^{-2} ; U=1090 \mathrm{~mW} \mathrm{~m}{ }^{-2}\end{array}$ & 77 \\
\hline \multicolumn{9}{|c|}{ d. Potentially-scalable bioelectrodes configurations (some studies were based on non-biogenic carbons) } \\
\hline Graphite granules fixed bed & - & $2-3.5 \mathrm{~mm}$ & n.r. & n.r. & n.r. & n.r. & $\begin{array}{l}\text { Measurements on single graphite granules in bed electrodes by } \\
\text { cyclic voltammetry. } \\
j=1.7-2.1 \mathrm{~mA} \mathrm{mg}^{-1} \text { of wet weight }\end{array}$ & 85 \\
\hline $\begin{array}{l}\text { Graphite particles/glassy } \\
\text { carbon particles }\end{array}$ & - & $\begin{array}{l}0.42 \text { to } 0.69 \mathrm{~mm} / 0.63 \text { to } 1 \\
\mathrm{~mm}\end{array}$ & n.r. & n.r. & n.r. & n.r. & $\begin{array}{l}\text { Studies on electron transfer mechanisms in microbial } \\
\text { electrochemical fluidized bed reactor } \\
j=2-10 \mathrm{~mA} \mathrm{~cm}^{-2} \text { imposed by potentiostats }\end{array}$ & 81,82 \\
\hline unspecified & n.r. & $\begin{array}{l}\text { Granules of } 1-3 \mathrm{~mm} \\
\text { diameter }\end{array}$ & 764 & n.r. & n.r. & n.r. & $\begin{array}{l}\text { Granular carbon biocathodes in methane-producing MET } \\
j=1 \mathrm{~mA} \mathrm{~cm}-2\end{array}$ & 83 \\
\hline Coke granules fixed bed & - & $5-20 \mathrm{~mm}$ & n.r. & n.r. & n.r. & n.r. & $\begin{array}{l}\text { 'METlands': integration of microbial electrochemical technolo- } \\
\text { gies with natural wastewater treatment biofilters } \\
j=1-4 \mathrm{~mA} \mathrm{dm}{ }^{-3} \text { of coke granules bed volume }\end{array}$ & 86 \\
\hline $\begin{array}{l}\text { Quercus wood biochar fixed } \\
\text { bed }\end{array}$ & & $6-12 \mathrm{~mm}$ & $\begin{array}{l}250\left(\mathrm{~N}_{2}\right. \\
\text { isoterm }) \\
550\left(\mathrm{CO}_{2}\right. \\
\text { isoterm })\end{array}$ & $\begin{array}{l}\text { Hierarchical } \\
\text { structure }\end{array}$ & 0.37 & $\begin{array}{l}\text { O, Phenols, } \\
\text { Quinones, } \\
\text { Fe, }\end{array}$ & $\begin{array}{l}\text { 'METlands': integration of microbial electrochemical technolo- } \\
\text { gies with natural wastewater treatment biofilters } \\
j=10 \mathrm{~mA} \mathrm{~cm}{ }^{-2} \text { measured on single granules }\end{array}$ & 15 \\
\hline
\end{tabular}

*ORR: Oxygen Reduction Reaction; OER: Oxygen Evolution Reaction; BET: Brunauer-Emmett-Teller method; $j$ : Current Density ranges or average (per geometric projected area or weight or volume of the electrode material); $U=$ Power density; n.r.: not reported; 
Table 2 - Properties and characterization techniques used to define e-biochar.

\begin{tabular}{|c|c|c|}
\hline Property & Technique & Parameters \\
\hline \multirow{2}{*}{ Electrical Conductivity } & Four-Point Probe Resistivity & \multirow{2}{*}{ Resistivity $(\Omega \mathrm{cm})$ or conductivity $(\mathrm{S} / \mathrm{cm})$} \\
\hline & AC impedance & \\
\hline \multirow{2}{*}{ Structural order } & $\mathrm{XRD} *$ & Features of (002) and (100) peaks \\
\hline & Raman & Features of $\mathrm{D}, \mathrm{G}$ and $2 \mathrm{D}$ bands \\
\hline \multirow[b]{2}{*}{ Surface chemistry } & XPS & Surface $\% \mathrm{C}, \mathrm{N}, \mathrm{S}, \mathrm{O}, \mathrm{P}$ and metals (and qualitative) \\
\hline & TPD-MS * & $\begin{array}{l}\mathrm{mmol}\left(\mathrm{CO}_{2} / \mathrm{CO} \text {-evolving O-functionality)/g e-biochar }\right. \\
\text { (and qualitative) }\end{array}$ \\
\hline Chemical composition & Elemental analysis ICP-MS & Bulk \% C, H, N, S, O, ash \\
\hline \multirow{3}{*}{ Porous texture } & $\mathrm{N}_{2}$ adsorption-desorption isotherms & $\mathrm{S}_{\mathrm{BET}}\left(\mathrm{m}^{2} / \mathrm{g}\right), V_{\text {micro }}$ and $V_{\text {meso }}\left(\mathrm{cm}^{3} / \mathrm{g}\right)$ \\
\hline & $\mathrm{CO}_{2}$ adsorption & $\mathrm{ACO}_{2}\left(\mathrm{~m}^{2} / \mathrm{g}\right), \mathrm{VCO}_{2}\left(\mathrm{~cm}^{3} / \mathrm{g}\right)$ \\
\hline & $\mathrm{Hg}$ porosimetry & VHg $\left(\mathrm{cm}^{3} / \mathrm{g}\right)$ macroporosity, porosity (\%), density \\
\hline Morphology & SEM * & Rugosity, pore size and shape \\
\hline \multirow{2}{*}{ Redox properties } & $\begin{array}{l}\text { Potentiostatic electrochemical } \\
\text { analysis }\end{array}$ & \multirow{2}{*}{$\begin{array}{l}\text { Electron-exchange Capacity (EEC) } \\
\text { Electron-Accepting Capacity (EAC) } \\
\text { Electron-Donating Capacity (EDC) }\end{array}$} \\
\hline & $\begin{array}{l}\text { Hydrodynamic electrochemical } \\
\text { techniques }\end{array}$ & \\
\hline \multirow{2}{*}{ Electrochemical properties } & $\mathrm{CV} *$ & \multirow{2}{*}{$\begin{array}{l}\text { Electrochemically-active surface area (EAS), electro-active } \\
\text { species, ion-diffusion, charge-transfer under abiotic conditions }\end{array}$} \\
\hline & EIS * & \\
\hline $\begin{array}{l}\text { Microbial electrochemical } \\
\text { properties }\end{array}$ & $\begin{array}{c}\text { Chronoamperometry, linear } \\
\text { voltammetry, } \\
\text { CV, EIS }\end{array}$ & $\begin{array}{l}\text { Electrogenic current density, bacteria-biochar charge transfer } \\
\text { (potential, current, resistance) }\end{array}$ \\
\hline $\begin{array}{l}\text { Biofilm morphology, } \\
\text { identification of } \\
\text { microorganisms }\end{array}$ & \multicolumn{2}{|c|}{ SEM, Confocal microscopy, FISH, DAPI * } \\
\hline Specific enzymatic activity & \multicolumn{2}{|c|}{ assessment of dehydrogenase activity (DH), fluorescein diacetate hydrolysis activity (FDA), others } \\
\hline $\begin{array}{l}\text { Microbial communities } \\
\text { composition and functional } \\
\text { analysis }\end{array}$ & \multicolumn{2}{|c|}{ 16S rDNA Illumina sequencing and/or rRNA intergenic spacer analysis (RISA) } \\
\hline
\end{tabular}

* CV: cyclic voltammetry; EIS: electrochemical impedance spectroscopy; SEM: scanning electron microscopy; TPD-MS: temperature-programmed desorption coupled to a mass spectrometer; XRD: X-ray diffraction; XPS: X-ray photoelectron spectroscopy; FISH: fluorescence in situ hybridization; DAPI: 4',6-diamidino2-phenylindole dye coupled to fluorescence microscope used for cells counting 
Figure 1 - Low-cost and widely available materials are needed for large-scale environmental applications of microbial electrochemical technologies (MET), when most high-tech materials are substantially excluded. Electroactive biochar (e-biochar) might open a new perspective. Residual biomass derived from agro-forestry and conventional biochars (a) undergo: mechanical pretreatments to set precise conformations (b), optimized thermochemical conversions and specific superficial treatments (c), to sustainably produce electroactive-biochar (e-biochar) (d), as base for the fabrication of bioelectrodes in possible large-scale MET (e). At end-of-life, such electrodes can be used in soil conditioning and e-biochar might contribute to soil fertility (f). The word 'electroactive', under the point of view of MET, includes a series of chemical/textural/structural properties that tend to simultaneously optimize: electroactive biofilm growth (g), microbial extracellular electron transfer (ET) mechanisms (h) and abiotic reversible redox reactions towards ET (i), surface area and pores texture (j), porosity distribution (k,l), surface redox and charge properties (capacitance), due to chemical composition (m) and sufficient electrical conductivity over given distances (n).

Figure 2 - Scanning electron microscopy (SEM) images of biochars synthesized by different groups in the literature: A-C) Prado et al., 2018 ; D) Pore size distributions from different techniques (considering DFT model and Washburn's equation for isotherms and porosimetry, respectively) of a quercus-derived biochar shown in A-C. Other SEM reports at different scales: a) Q. Chen et al., 2018; b) Lin et al., 2017; c) Ma et al., 2016; d) Yuan et al., 2014; e) Zha et al., 2016 (Chen et al. 2018; Lin et al. 2017; Ma et al. 2016; Yuan et al. 2014; Zha et al. 2016). SEM images demonstrating biochar-mediated interspecies electron transfer in f) G. metallireducens and G. sulfurreducens and g) G. metallireducens (rods) and M. barkeri (spheres) co-cultures (Chen et al. 2014). Reprinted (adapted) with permission from (Chen et al. 2018; Lin et al. 2017; Ma et al. 2016; Yuan et al. 2014; Zha et al. 2016). Copyright (C) 2017, American Chemical Society and Elsevier. 


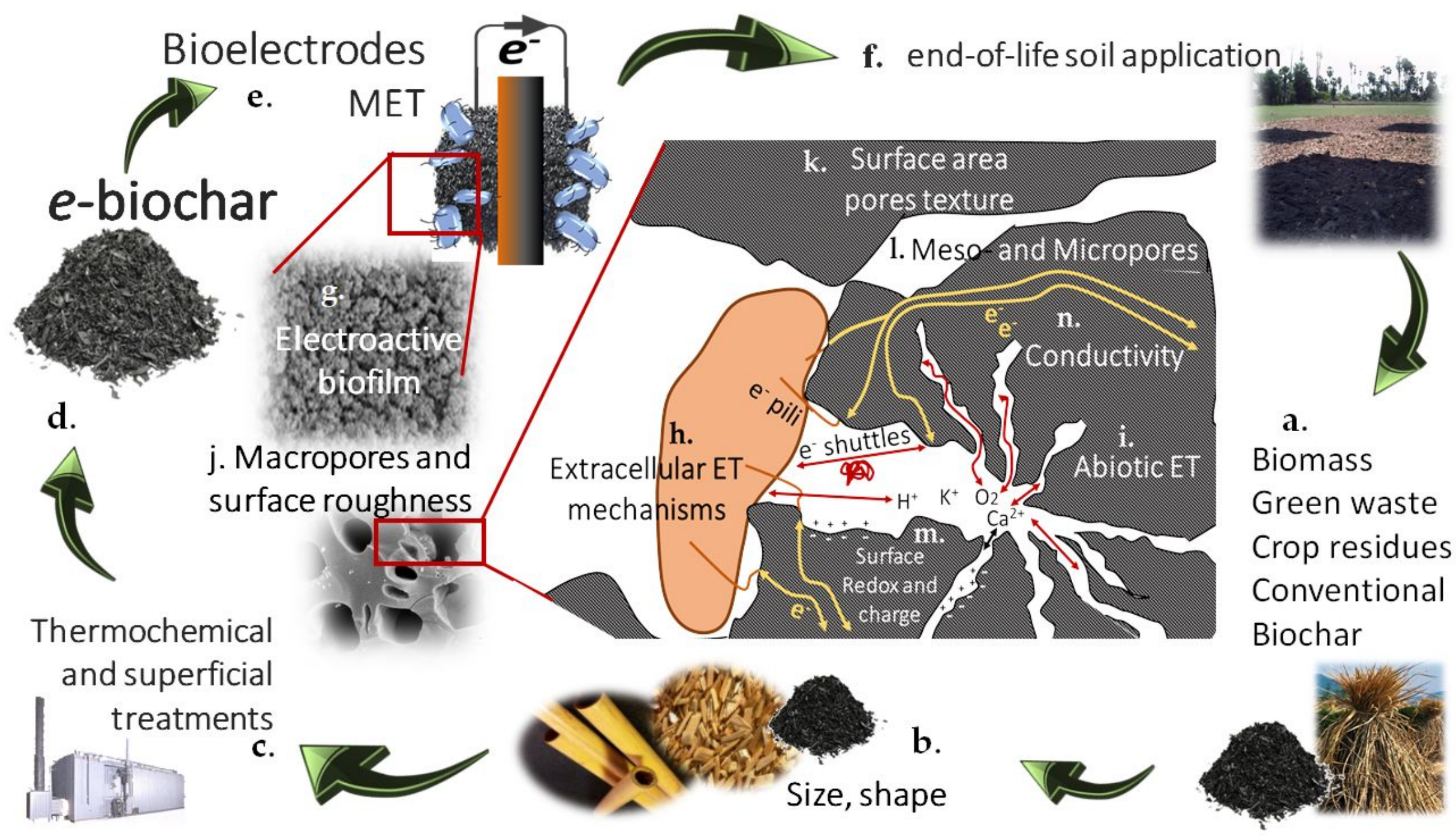

Figure 1 

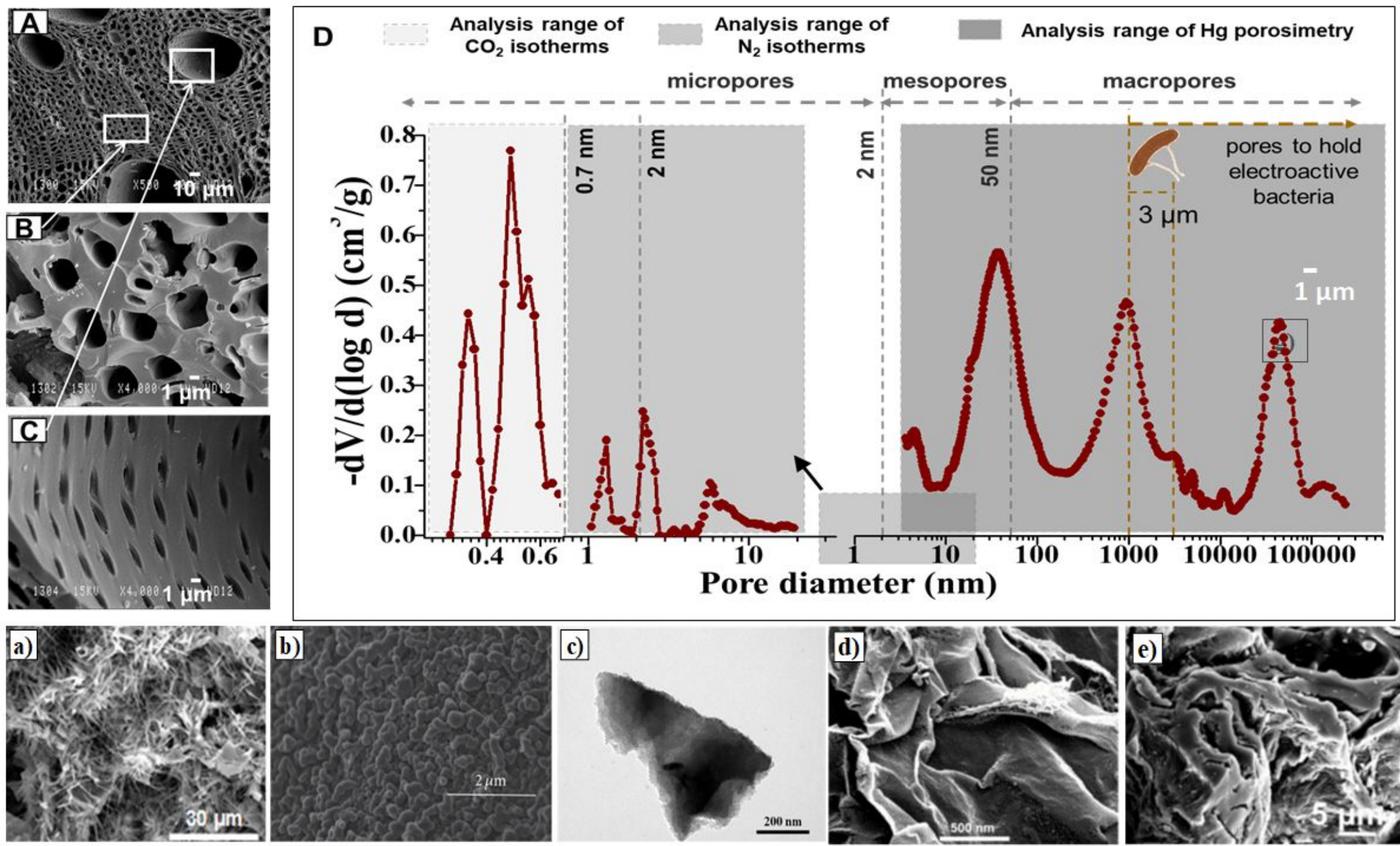

Figure 2 


\section{References}

(1) Kracke, F.; Vassilev, I.; Krömer, J. O. Microbial Electron Transport and Energy Conservation - the Foundation for Optimizing Bioelectrochemical Systems. Front. Microbiol. 2015, 6 (Jun), 575. https://doi.org/10.3389/fmicb.2015.00575.

(2) Xie, X.; Criddle, C.; Cui, Y. Design and Fabrication of Bioelectrodes for Microbial Bioelectrochemical Systems. Energy Environ. Sci. 2015, 8 (12), 3418-3441. https://doi.org/10.1039/c5ee01862e.

(3) Wei, J.; Liang, P.; Huang, X. Recent Progress in Electrodes for Microbial Fuel Cells. Bioresour. Technol. 2011, 102 (20), 9335-9344. https://doi.org/10.1016/j.biortech.2011.07.019.

(4) Goglio, A.; Tucci, M.; Rizzi, B.; Colombo, A.; Cristiani, P.; Schievano, A. Microbial Recycling Cells (MRCs): A New Platform of Microbial Electrochemical Technologies Based on Biocompatible Materials, Aimed at Cycling Carbon and Nutrients in Agro-Food Systems. Sci. Total Environ. 2019, 649, 1349-1361. https://doi.org/10.1016/J.SCITOTENV.2018.08.324.

(5) Daud, S. M.; Kim, B. H.; Ghasemi, M.; Daud, W. R. W. Separators Used in Microbial Electrochemical Technologies: Current Status and Future Prospects. Bioresour. Technol. 2015, 195, 170-179. https://doi.org/10.1016/j.biortech.2015.06.105.

(6) Logan, B. E.; Hamelers, B.; Rozendal, R.; Schröder, U.; Keller, J.; Freguia, S.; Aelterman, P.; Verstraete, W.; Rabaey, K. Microbial Fuel Cells: Methodology and Technology. Environ. Sci. Technol. 2006, 40 (17), 5181-5192. https://doi.org/10.1021/es0605016.

(7) Wang, H.; Ren, Z. J. A Comprehensive Review of Microbial Electrochemical Systems as a Platform Technology. Biotechnol. Adv. 2013, 31 (8), 1796-1807. https://doi.org/10.1016/j.biotechadv.2013.10.001.

(8) Krieg, T.; Sydow, A.; Schröder, U.; Schrader, J.; Holtmann, D. Reactor Concepts for Bioelectrochemical Syntheses and Energy Conversion. Trends Biotechnol. 2014, 32 (12), 645-655. https://doi.org/10.1016/j.tibtech.2014.10.004.

(9) Rossi, R.; Jones, D.; Myung, J.; Zikmund, E.; Yang, W.; Gallego, Y. A.; Pant, D.; Evans, P. J.; Page, M. A.; Cropek, D. M.; et al. Evaluating a Multi-Panel Air Cathode through Electrochemical and Biotic Tests. Water Res. 2019, 148, 51-59. https://doi.org/10.1016/j.watres.2018.10.022.

(10) Zhang, J.; Yuan, H.; Deng, Y.; Zha, Y.; Abu-Reesh, I. M.; He, Z.; Yuan, C. Life Cycle Assessment of a Microbial Desalination Cell for Sustainable Wastewater Treatment and Saline Water Desalination. J. Clean. Prod. 2018, 200, 900-910. https://doi.org/10.1016/J.JCLEPRO.2018.07.197.

(11) Santoro, C.; Artyushkova, K.; Babanova, S.; Atanassov, P.; leropoulos, I.; Grattieri, M.; Cristiani, P.; Trasatti, S.; Li, B.; Schuler, A. J. Parameters Characterization and Optimization of Activated Carbon (AC) Cathodes for Microbial Fuel Cell Application. Bioresour. Technol. 2014, 163, 54-63. https://doi.org/10.1016/j.biortech.2014.03.091.

(12) Qian, K.; Kumar, A.; Zhang, H.; Bellmer, D.; Huhnke, R. Recent Advances in Utilization of Biochar. Renewable and Sustainable Energy Reviews. Pergamon 2015, pp 1055-1064. https://doi.org/10.1016/j.rser.2014.10.074.

(13) Bachmann, H. J.; Bucheli, T. D.; Dieguez-Alonso, A.; Fabbri, D.; Knicker, H.; Schmidt, H.-P.; Ulbricht, A.; Becker, R.; Buscaroli, A.; Buerge, D.; et al. Toward the Standardization of Biochar Analysis: The COST Action TD1107 Interlaboratory Comparison. J. Agric. Food Chem. 2016, 64 (2), 513-527. https://doi.org/10.1021/acs.jafc.5b05055.

(14) Chen, S.; Rotaru, A.-E.; Shrestha, P. M.; Malvankar, N. S.; Liu, F.; Fan, W.; Nevin, K. P.; Lovley, D. R. Promoting Interspecies Electron Transfer with Biochar. Sci. Rep. 2014, 4, 5019. https://doi.org/10.1038/srep05019. 
(15) Prado, A.; Berenguer, R.; Esteve-Núñez, A. Electroactive Biochar Outperforms Highly Conductive Carbon Materials for Biodegrading Pollutants by Enhancing Microbial Extracellular Electron Transfer. Carbon N. Y. 2019, 146, 597-609. https://doi.org/10.1016/J.CARBON.2019.02.038.

(16) Atkinson, C. J.; Fitzgerald, J. D.; Hipps, N. A. Potential Mechanisms for Achieving Agricultural Benefits from Biochar Application to Temperate Soils: A Review. Plant Soil 2010, 337 (1-2), 1-18. https://doi.org/10.1007/s11104-010-0464-5.

(17) Lehmann, J.; Rillig, M. C.; Thies, J.; Masiello, C. A.; Hockaday, W. C.; Crowley, D. Biochar Effects on Soil Biota - A Review. Soil Biol. Biochem. 2011, 43 (9), 1812-1836.

https://doi.org/10.1016/j.soilbio.2011.04.022.

(18) Komang T., R.-S.; Caroline, H. O. Biochar Application Essential Soil Microbial Ecology; Elsevier Science, 2016. https://doi.org/http://dx.doi.org/10.1016/B978-0-12-803433-0.00001-1.

(19) Tong, H.; Hu, M.; Li, F. B.; Liu, C. S.; Chen, M. J. Biochar Enhances the Microbial and Chemical Transformation of Pentachlorophenol in Paddy Soil. Soil Biol. Biochem. 2014, 70, 142-150. https://doi.org/10.1016/j.soilbio.2013.12.012.

(20) Kappler, A.; Wuestner, M. L.; Ruecker, A.; Harter, J.; Halama, M.; Behrens, S. Biochar as an Electron Shuttle between Bacteria and Fe(III) Minerals. Environ. Sci. Technol. Lett. 2014, 1 (8), 339-344. https://doi.org/10.1021/ez5002209.

(21) Yu, L.; Yuan, Y.; Tang, J.; Wang, Y.; Zhou, S. Biochar as an Electron Shuttle for Reductive Dechlorination of Pentachlorophenol by Geobacter Sulfurreducens. Sci. Rep. 2015, 5 (1), 16221. https://doi.org/10.1038/srep16221.

(22) Saquing, J. M.; Yu, Y. H.; Chiu, P. C. Wood-Derived Black Carbon (Biochar) as a Microbial Electron Donor and Acceptor. Environ. Sci. Technol. Lett. 2016. https://doi.org/10.1021/acs.estlett.5b00354.

(23) Yu, L.; Wang, Y.; Yuan, Y.; Tang, J.; Zhou, S. Biochar as Electron Acceptor for Microbial Extracellular Respiration. Geomicrobiol. J. 2016, 33 (6), 530-536. https://doi.org/10.1080/01490451.2015.1062060.

(24) Chen, Z.; Wang, Y.; Xia, D.; Jiang, X.; Fu, D.; Shen, L.; Wang, H.; Li, Q. B. Enhanced Bioreduction of Iron and Arsenic in Sediment by Biochar Amendment Influencing Microbial Community Composition and Dissolved Organic Matter Content and Composition. J. Hazard. Mater. 2016, 311 (422), $20-29$. https://doi.org/10.1016/j.jhazmat.2016.02.069.

(25) Yuan, Y.; Bolan, N.; Prévoteau, A.; Vithanage, M.; Biswas, J. K.; Ok, Y. S.; Wang, H. Applications of Biochar in Redox-Mediated Reactions. Bioresour. Technol. 2017, 246, 271-281. https://doi.org/10.1016/j.biortech.2017.06.154.

(26) Sun, T.; Levin, B. D. A.; Guzman, J. J. L.; Enders, A.; Muller, D. A.; Angenent, L. T.; Lehmann, J. Rapid Electron Transfer by the Carbon Matrix in Natural Pyrogenic Carbon. Nat. Commun. 2017, 8, 14873. https://doi.org/10.1038/ncomms14873.

(27) Gralnick, J. A.; Newman, D. K. Extracellular Respiration. Mol. Microbiol. 2007, 65 (1), 1-11. https://doi.org/10.1111/j.1365-2958.2007.05778.x.

(28) Chacón, F. J.; Cayuela, M. L.; Roig, A.; Sánchez-Monedero, M. A. Understanding, Measuring and Tuning the Electrochemical Properties of Biochar for Environmental Applications. Rev. Environ. Sci. Bio/Technology 2017, 16 (4), 695-715. https://doi.org/10.1007/s11157-017-9450-1.

(29) Schievano, A.; Goglio, A.; Erckert, C.; Marzorati, S.; Rago, L.; Cristiani, P. Organic Waste and Bioelectrochemical Systems: A Future Interface between Electricity and Methane Distribution Grids. Detritus 2018, 01, 57-63.

(30) Costa, N. L.; Clarke, T. A.; Philipp, L.-A.; Gescher, J.; Louro, R. O.; Paquete, C. M. Electron Transfer 
(31) Schroeder, U.; Harnisch, F. Life Electric - Nature as a Blueprint for the Development of Microbial Electrochemical Technologies. Joule 2017, 244-252. https://doi.org/10.1016/j.joule.2017.07.010.

(32) Huggins, T.; Wang, H.; Kearns, J.; Jenkins, P.; Ren, Z. J. Biochar as a Sustainable Electrode Material for Electricity Production in Microbial Fuel Cells. Bioresour. Technol. 2014, 157, 114-119. https://doi.org/10.1016/j.biortech.2014.01.058.

(33) Tabti, Z.; Berenguer, R.; Ruiz-Rosas, R.; Quijada, C.; Morallon, E.; CAZORLA-AMOR^|^Oacute;S, D. Electrooxidation Methods to Produce Pseudocapacitance-Containing Porous Carbons. Electrochemistry 2013, 81 (10), 833-839. https://doi.org/10.5796/electrochemistry.81.833.

(34) Fitzer, E.; Kochling, K.-H.; Boehm, H. P.; Marsh, H. Recommended Terminology for the Description of Carbon as a Solid (IUPAC Recommendations 1995). Pure Appl. Chem. 1995, 67 (3), 473-506. https://doi.org/10.1351/pac199567030473.

(35) Berenguer, R.; García-Mateos, F. J.; Ruiz-Rosas, R.; Cazorla-Amorós, D.; Morallón, E.; RodríguezMirasol, J.; Cordero, T. Biomass-Derived Binderless Fibrous Carbon Electrodes for Ultrafast Energy Storage. Green Chem. 2016, 18 (6), 1506-1515. https://doi.org/10.1039/c5gc02409a.

(36) Menendez, J. A.; Xia, B.; Phillips, J.; Radovic, L. R. On the Modification and Characterization of Chemical Surface Properties of Activated Carbon : Microcalorimetric, Electrochemical , and Thermal Desorption Probes. Langmuir 1997, 13 (19), 3414-3421. https://doi.org/10.1021/la970200x.

(37) Bandosz, T. J.; Ania, C. O. Activated Carbon Surfaces in Environmental Remediation. Interface Sci. Technol. 2006, 7, 159-229. https://doi.org/10.1016/S1573-4285(06)80013-X.

(38) Montes-Morán, M. A.; Suárez, D.; Menéndez, J. A.; Fuente, E. On the Nature of Basic Sites on Carbon Surfaces: An Overview. Carbon N. Y. 2004, 42 (7), 1219-1224.

https://doi.org/10.1016/j.carbon.2004.01.023.

(39) Ruiz-Rosas, R.; Valero-Romero, M. J.; Salinas-Torres, D.; Rodríguez-Mirasol, J.; Cordero, T.; Morallón, E.; Cazorla-Amorós, D. Electrochemical Performance of Hierarchical Porous Carbon Materials Obtained from the Infiltration of Lignin into Zeolite Templates. ChemSusChem 2014, 7 (5), 14581467. https://doi.org/10.1002/cssc.201301408.

(40) Rosas, J. M.; Berenguer, R.; Valero-Romero, M. J.; RodrÃ-guez-Mirasol, J.; Cordero, T. Preparation of Different Carbon Materials by Thermochemical Conversion of Lignin. Front. Mater. 2014, 1, 29. https://doi.org/10.3389/fmats.2014.00029.

(41) Figueiredo, J. .; Pereira, M. F. .; Freitas, M. M. .; Órfão, J. J. . Modification of the Surface Chemistry of Activated Carbons. Carbon N. Y. 1999, 37 (9), 1379-1389. https://doi.org/10.1016/S00086223(98)00333-9.

(42) Klüpfel, L.; Keiluweit, M.; Kleber, M.; Sander, M. Redox Properties of Plant Biomass-Derived Carbon Black (Biochar). Env. Sci Technol 2014, 48, 5601-5611. https://doi.org/10.1021/es500906d.

(43) Bleda-Martínez, M. J.; Lozano-Castelló, D.; Morallón, E.; Cazorla-Amorós, D.; Linares-Solano, A. Chemical and Electrochemical Characterization of Porous Carbon Materials. Carbon N. Y. 2006, 44 (13), 2642-2651. https://doi.org/10.1016/j.carbon.2006.04.017.

(44) Berenguer, R.; Ruiz-Rosas, R.; Gallardo, A.; Cazorla-Amorós, D.; Morallón, E.; Nishihara, H.; Kyotani, T.; Rodríguez-Mirasol, J.; Cordero, T. Enhanced Electro-Oxidation Resistance of Carbon Electrodes Induced by Phosphorus Surface Groups. Carbon N. Y. 2015, 95, 681-689. https://doi.org/10.1016/j.carbon.2015.08.101.

(45) Itoi, H.; Nishihara, H.; Ishii, T.; Nueangnoraj, K.; Berenguer-Betrián, R.; Kyotani, T. Large 
Pseudocapacitance in Quinone-Functionalized Zeolite-Templated Carbon. Bull. Chem. Soc. Jpn. 2014, 87 (2), 250-257. https://doi.org/10.1246/bcsj.20130292.

(46) Valero-Romero, M. J.; García-Mateos, F. J.; Rodríguez-Mirasol, J.; Cordero, T. Role of Surface Phosphorus Complexes on the Oxidation of Porous Carbons. Fuel Process. Technol. 2017, 157 (January 2018), 116-126. https://doi.org/10.1016/j.fuproc.2016.11.014.

(47) Joseph, S.; Graber, E.; Chia, C.; Munroe, P.; Donne, S.; Thomas, T.; Nielsen, S.; Marjo, C.; Rutlidge, H.; Pan, G.; et al. Shifting Paradigms: Development of High-Efficiency Biochar Fertilizers Based on NanoStructures and Soluble Components. Carbon Manag. 2013, 4 (3), 323-343.

https://doi.org/10.4155/cmt.13.23.

(48) Ruiz-Rosas, R.; Bedia, J.; Lallave, M.; Loscertales, I. G.; Barrero, A.; Rodríguez-Mirasol, J.; Cordero, T. The Production of Submicron Diameter Carbon Fibers by the Electrospinning of Lignin. Carbon N. Y. 2010, 48 (3), 696-705. https://doi.org/10.1016/j.carbon.2009.10.014.

(49) Radovic, L. R.; Bockrath, B. On the Chemical Nature of Graphene Edges: Origin of Stability and Potential for Magnetism in Carbon Materials. J. Am. Chem. Soc. 2005, 127 (16), 5917-5927. https://doi.org/10.1021/ja050124h.

(50) Rodríguez-Reinoso, F.; Molina-Sabio, M. Activated Carbons from Lignocellulosic Materials by Chemical and/or Physical Activation: An Overview. Carbon N. Y. 1992, 30 (7), 1111-1118. https://doi.org/10.1016/0008-6223(92)90143-K.

(51) Ternero-Hidalgo, J. J.; Rosas, J. M.; Palomo, J.; Valero-Romero, M. J.; Rodríguez-Mirasol, J.; Cordero, T. Functionalization of Activated Carbons by HNO3treatment: Influence of Phosphorus Surface Groups. Carbon N. Y. 2016, 101, 409-419. https://doi.org/10.1016/j.carbon.2016.02.015.

(52) Mostazo-López, M. J.; Ruiz-Rosas, R.; Morallón, E.; Cazorla-Amorós, D. Generation of Nitrogen Functionalities on Activated Carbons by Amidation Reactions and Hofmann Rearrangement: Chemical and Electrochemical Characterization. Carbon N. Y. 2015, 91, 252-265. https://doi.org/10.1016/j.carbon.2015.04.089.

(53) Sharma, M.; Alvarez-Gallego, Y.; Achouak, W.; Pant, D.; Sharma, P.; Dominguez-Benetton, X. Electrode Material Properties for Designing Effective Microbial Electrosynthesis Systems. J. Mater. Chem. A 2019. https://doi.org/10.1039/C9TA04886C.

(54) Prévoteau, A.; Ronsse, F.; Cid, I.; Boeckx, P.; Rabaey, K. The Electron Donating Capacity of Biochar Is Dramatically Underestimated. Sci. Rep. 2016, 6 (1), 32870. https://doi.org/10.1038/srep32870.

(55) Sharma, M.; Bajracharya, S.; Gildemyn, S.; Patil, S. a.; Alvarez-Gallego, Y.; Pant, D.; Rabaey, K.; Dominguez-Benetton, X. A Critical Revisit of the Key Parameters Used to Describe Microbial Electrochemical Systems. Electrochim. Acta 2014, No. September 2015. https://doi.org/10.1016/j.electacta.2014.02.111.

(56) Chen, S.; Tang, J.; Fu, L.; Yuan, Y.; Zhou, S. Biochar Improves Sediment Microbial Fuel Cell Performance in Low Conductivity Freshwater Sediment. J. Soils Sediments 2016, 16 (9), 2326-2334. https://doi.org/10.1007/s11368-016-1452-z.

(57) Chen, Q.; Pu, W.; Hou, H.; Hu, J.; Liu, B.; Li, J.; Cheng, K.; Huang, L.; Yuan, X.; Yang, C.; et al. Activated Microporous-Mesoporous Carbon Derived from Chestnut Shell as a Sustainable Anode Material for High Performance Microbial Fuel Cells. Bioresour. Technol. 2018, 249, 567-573. https://doi.org/10.1016/j.biortech.2017.09.086.

(58) Liu, Y.; He, P.; Shao, L.; Zhang, H.; Lü, F. Significant Enhancement by Biochar of Caproate Production via Chain Elongation. Water Res. 2017, 119, 150-159. https://doi.org/10.1016/j.watres.2017.04.050.

(59) Qin, Y.; Wang, H.; Li, X.; Cheng, J. J.; Wu, W. Improving Methane Yield from Organic Fraction of 
(61) Cruz Viggi, C.; Simonetti, S.; Palma, E.; Pagliaccia, P.; Braguglia, C.; Fazi, S.; Baronti, S.; Navarra, M. A.; Pettiti, I.; Koch, C.; et al. Enhancing Methane Production from Food Waste Fermentate Using Biochar: The Added Value of Electrochemical Testing in Pre-Selecting the Most Effective Type of Biochar. Biotechnol. Biofuels 2017, 10 (1), 303. https://doi.org/10.1186/s13068-017-0994-7.

(62) Mumme, J.; Srocke, F.; Heeg, K.; Werner, M. Use of Biochars in Anaerobic Digestion. Bioresour. Technol. 2014, 164, 189-197. https://doi.org/10.1016/J.BIORTECH.2014.05.008.

(63) Tan, Z.; Lin, C. S. K.; Ji, X.; Rainey, T. J. Returning Biochar to Fields: A Review. Applied Soil Ecology. 2017, pp 1-11. https://doi.org/10.1016/j.apsoil.2017.03.017.

(64) Chen, S.; He, G.; Hu, X.; Xie, M.; Wang, S.; Zeng, D.; Hou, H.; Schröder, U. A Three-Dimensionally Ordered Macroporous Carbon Derived from a Natural Resource as Anode for Microbial Bioelectrochemical Systems. ChemSusChem 2012, 5 (6), 1059-1063. https://doi.org/10.1002/cssc.201100783.

(65) Vijayaraj, M.; Gadiou, R.; Anselme, K.; Ghimbeu, C.; Vix-Guterl, C.; Orikasa, H.; Kyotani, T.; Ittisanronnachai, S. The Influence of Surface Chemistry and Pore Size on the Adsorption of Proteins on Nanostructured Carbon Materials. Adv. Funct. Mater. 2010, 20 (15), 2489-2499. https://doi.org/10.1002/adfm.201000288.

(66) Champigneux, P.; Delia, M.-L.; Bergel, A. Impact of Electrode Micro- and Nano-Scale Topography on the Formation and Performance of Microbial Electrodes. Biosens. Bioelectron. 2018, 118 (June), 231-246. https://doi.org/10.1016/j.bios.2018.06.059.

(67) Santoro, C.; Artyushkova, K.; Babanova, S.; Atanassov, P.; leropoulos, I.; Grattieri, M.; Cristiani, P.; Trasatti, S.; Li, B.; Schuler, A. J. Parameters Characterization and Optimization of Activated Carbon (AC) Cathodes for Microbial Fuel Cell Application. Bioresour. Technol. 2014, 163, 54-63. https://doi.org/10.1016/j.biortech.2014.03.091.

(68) Paquete, C. M.; Fonseca, B. M.; Cruz, D. R.; Pereira, T. M.; Pacheco, I.; Soares, C. M.; Louro, R. O. Exploring the Molecular Mechanisms of Electron Shuttling across the Microbe/Metal Space. Front. Microbiol. 2014, 5, 318. https://doi.org/10.3389/fmicb.2014.00318.

(69) Gorby, Y. A.; Yanina, S.; McLean, J. S.; Rosso, K. M.; Moyles, D.; Dohnalkova, A.; Beveridge, T. J.; Chang, I. S.; Kim, B. H.; Kim, K. S.; et al. Electrically Conductive Bacterial Nanowires Produced by Shewanella Oneidensis Strain MR-1 and Other Microorganisms. Proc. Natl. Acad. Sci. U. S. A. 2006, 103 (30), 11358-11363. https://doi.org/10.1073/pnas.0604517103.

(70) Xiao, Y.; Zhang, E.; Zhang, J.; Dai, Y.; Yang, Z.; Christensen, H. E. M.; Ulstrup, J.; Zhao, F. Extracellular Polymeric Substances Are Transient Media for Microbial Extracellular Electron Transfer. Sci. Adv. 2017, 3 (7), e1700623. https://doi.org/10.1126/sciadv.1700623.

(71) Marzorati, S.; Goglio, A.; Fest-Santini, S.; Mombelli, D.; Villa, F.; Cristiani, P.; Schievano, A. AirBreathing Bio-Cathodes Based on Electro-Active Biochar from Pyrolysis of Giant Cane Stalks. Int. J. Hydrogen Energy 2018. https://doi.org/10.1016/J.IJHYDENE.2018.07.167.

(72) Walter, X. A.; Greenman, J.; leropoulos, I. Binder Materials for the Cathodes Applied to SelfStratifying Membraneless Microbial Fuel Cell. Bioelectrochemistry 2018, 123, 119-124. https://doi.org/10.1016/J.BIOELECHEM.2018.04.011. 
(73) Guo, K.; Pré, A.; Patil, S. A.; Rabaey, K. Engineering Electrodes for Microbial Electrocatalysis. Curr. Opin. Biotechnol. 2015, 33, 149-156. https://doi.org/10.1016/j.copbio.2015.02.014.

(74) Logan, B. E. Scaling up Microbial Fuel Cells and Other Bioelectrochemical Systems. Appl. Microbiol. Biotechnol. 2010, 85 (6), 1665-1671. https://doi.org/10.1007/s00253-009-2378-9.

(75) Pant, D.; Singh, A.; Van Bogaert, G.; Gallego, Y. A.; Diels, L.; Vanbroekhoven, K. An Introduction to the Life Cycle Assessment (LCA) of Bioelectrochemical Systems (BES) for Sustainable Energy and Product Generation: Relevance and Key Aspects. Renew. Sustain. Energy Rev. 2011, 15 (2), 13051313. https://doi.org/10.1016/J.RSER.2010.10.005.

(76) Foley, J. M.; Rozendal, R. A.; Hertle, C. K.; Lant, P. A.; Rabaey, K. Life Cycle Assessment of High-Rate Anaerobic Treatment, Microbial Fuel Cells, and Microbial Electrolysis Cells. Environ. Sci. Technol. 2010, 44 (9), 3629-3637. https://doi.org/10.1021/es100125h.

(77) Yuan, Y.; Zhou, S.; Liu, Y.; Tang, J. Nanostructured Macroporous Bioanode Based on PolyanilineModified Natural Loofah Sponge for High-Performance Microbial Fuel Cells. Environ. Sci. Technol. 2013, 47 (24), 14525-14532. https://doi.org/10.1021/es404163g.

(78) Chen, S.; Liu, Q.; He, G.; Zhou, Y.; Hanif, M.; Peng, X.; Wang, S.; Hou, H. Reticulated Carbon Foam Derived from a Sponge-like Natural Product as a High-Performance Anode in Microbial Fuel Cells. J. Mater. Chem. 2012, 22 (35), 18609. https://doi.org/10.1039/c2jm33733a.

(79) Li, J.; Zhang, J.; Ye, D.; Zhu, X.; Liao, Q.; Zheng, J. Optimization of Inner Diameter of Tubular Bamboo Charcoal Anode for a Microbial Fuel Cell. Int. J. Hydrogen Energy 2014, 39 (33), 19242-19248. https://doi.org/10.1016/j.ijhydene.2014.04.124.

(80) Marzorati, S.; Goglio, A.; Mombelli, D.; Mapelli, C.; Trasatti, S. P.; Cristiani, P.; Schievano, A. Giant Cane as Low-Cost Material for Microbial Fuel Cells Architectures. In Proceedings of EFC2017 European Fuel Cell Technology \& Applications Conference - Piero Lunghi Conference December 1215, 2017, Naples, Italy; 2017; p 114.

(81) Tejedor-Sanz, S.; Ortiz, J. M.; Esteve-Núñez, A. Merging Microbial Electrochemical Systems with Electrocoagulation Pretreatment for Achieving a Complete Treatment of Brewery Wastewater. Chem. Eng. J. 2017, 330, 1068-1074. https://doi.org/10.1016/j.cej.2017.08.049.

(82) Tejedor-Sanz, S.; Quejigo, J. R.; Berná, A.; Esteve-Núñez, A. The Planktonic Relationship Between Fluid-Like Electrodes and Bacteria: Wiring in Motion. ChemSusChem 2017, 10 (4), 693-700. https://doi.org/10.1002/cssc.201601329.

(83) Liu, D.; Roca-puigros, M.; Geppert, F.; Caizán-juanarena, L. Granular Carbon-Based Electrodes as Cathodes in Methane-Producing Bioelectrochemical Systems. 2018, 6 (June), 1-10. https://doi.org/10.3389/fbioe.2018.00078.

(84) Ghafari, S.; Hasan, M.; Aroua, M. K. Nitrate Remediation in a Novel Upflow Bio-Electrochemical Reactor (UBER) Using Palm Shell Activated Carbon as Cathode Material. Electrochim. Acta 2009, 54 (17), 4164-4171. https://doi.org/10.1016/j.electacta.2009.02.062.

(85) Rodrigo Quejigo, J.; Rosa, L. F. M.; Harnisch, F. Electrochemical Characterization of Bed Electrodes Using Voltammetry of Single Granules. Electrochem. commun. 2018, 90, 78-82. https://doi.org/10.1016/J.ELECOM.2018.04.009.

(86) Aguirre-Sierra, A.; Bacchetti-De Gregoris, T.; Berná, A.; Salas, J. J.; Aragón, C.; Esteve-Núñez, A. Microbial Electrochemical Systems Outperform Fixed-Bed Biofilters in Cleaning up Urban Wastewater. Environ. Sci. Water Res. Technol. 2016, 2 (6), 984-993. https://doi.org/10.1039/C6EW00172F.

(87) Prado, A.; Berenguer, R.; Esteve-Núñez, A. Electroconductive Carbon Biofilters for Efficient and 
(89) Ma, M.; You, S.; Wang, W.; Liu, G.; Qi, D.; Chen, X.; Qu, J.; Ren, N. Biomass-Derived Porous Fe3C/Tungsten Carbide/Graphitic Carbon Nanocomposite for Efficient Electrocatalysis of Oxygen Reduction. ACS Appl. Mater. Interfaces 2016, 8 (47), 32307-32316. https://doi.org/10.1021/acsami.6b10804.

(90) Yuan, S.-J.; Dai, X.-H.; Jaroniec, M.; Qiao, S. Z.; Zhang, D. Y. H.; Che, R. C.; Tang, Y.; Su, D. S.; Asiri, A. M.; Zhao, D. Y.; et al. An Efficient Sewage Sludge-Derived Bi-Functional Electrocatalyst for Oxygen Reduction and Evolution Reaction. Green Chem. 2016, 18 (14), 4004-4011. https://doi.org/10.1039/C5GC02729B.

(91) Nieva Lobos, M. L.; Sieben, J. M.; Comignani, V.; Duarte, M.; Volpe, M. A.; Moyano, E. L. Biochar from Pyrolysis of Cellulose: An Alternative Catalyst Support for the Electro-Oxidation of Methanol. Int. J. Hydrogen Energy 2016, 41 (25), 10695-10706. https://doi.org/10.1016/j.ijhydene.2016.04.041.

(92) Zha, D. W.; Li, L. F.; Pan, Y. X.; He, J. B. Coconut Shell Carbon Nanosheets Facilitating Electron Transfer for Highly Efficient Visible-Light-Driven Photocatalytic Hydrogen Production from Water. Int. J. Hydrogen Energy 2016, 41 (39), 17370-17379. https://doi.org/10.1016/j.ijhydene.2016.07.227.

(93) Lin, X.; Wang, X.; Li, L.; Yan, M.; Tian, Y. Rupturing Cotton Microfibers into Mesoporous NitrogenDoped Carbon Nanosheets as Metal-Free Catalysts for Efficient Oxygen Electroreduction. ACS Sustain. Chem. Eng. 2017, 5 (11), 9709-9717. https://doi.org/10.1021/acssuschemeng.7b01398.

(94) Mendonça, F. G. de; Cunha, I. T. da; Soares, R. R.; Tristão, J. C.; Lago, R. M. Tuning the Surface Properties of Biochar by Thermal Treatment. Bioresour. Technol. 2017, 246 (May), 28-33. https://doi.org/10.1016/j.biortech.2017.07.099.

(95) Tong, H.; Hu, M.; Li, F. B.; Liu, C. S.; Chen, M. J. Biochar Enhances the Microbial and Chemical Transformation of Pentachlorophenol in Paddy Soil. Soil Biol. Biochem. 2014, 70, 142-150. https://doi.org/10.1016/j.soilbio.2013.12.012.

(96) Wang, S.; Zheng, Y.; Yan, W.; Chen, L.; Dummi Mahadevan, G.; Zhao, F. Enhanced Bioleaching Efficiency of Metals from E-Wastes Driven by Biochar. J. Hazard. Mater. 2016, 320, 393-400. https://doi.org/10.1016/j.jhazmat.2016.08.054.

(97) Chen, G.; Zhang, Z.; Zhang, Z.; Zhang, R. Redox-Active Reactions in Denitrification Provided by Biochars Pyrolyzed at Different Temperatures. Sci. Total Environ. 2017, 615, 1547-1556. https://doi.org/10.1016/j.scitotenv.2017.09.125.

(98) Huggins, T. M.; Pietron, J. J.; Wang, H.; Ren, Z. J.; Biffinger, J. C. Graphitic Biochar as a Cathode Electrocatalyst Support for Microbial Fuel Cells. Bioresour. Technol. 2015, 195, 147-153. https://doi.org/10.1016/J.BIORTECH.2015.06.012.

(99) Yuan, H.; Deng, L.; Qi, Y.; Kobayashi, N.; Tang, J. Nonactivated and Activated Biochar Derived from Bananas as Alternative Cathode Catalyst in Microbial Fuel Cells. Sci. World J. 2014, 2014, 832-850. https://doi.org/10.1155/2014/832850.

(100) Li, M.; Zhang, H.; Xiao, T.; Wang, S.; Zhang, B.; Chen, D.; Su, M.; Tang, J. Low-Cost Biochar Derived from Corncob as Oxygen Reduction Catalyst in Air Cathode Microbial Fuel Cells. Electrochim. Acta 2018, 283, 780-788. https://doi.org/10.1016/J.ELECTACTA.2018.07.010. 
(101) Karthikeyan, R.; Wang, B.; Xuan, J.; Wong, J. W. C.; Lee, P. K. H.; Leung, M. K. H. Interfacial Electron Transfer and Bioelectrocatalysis of Carbonized Plant Material as Effective Anode of Microbial Fuel Cell. Electrochim. Acta 2015, 157, 314-323. https://doi.org/10.1016/j.electacta.2015.01.029. 


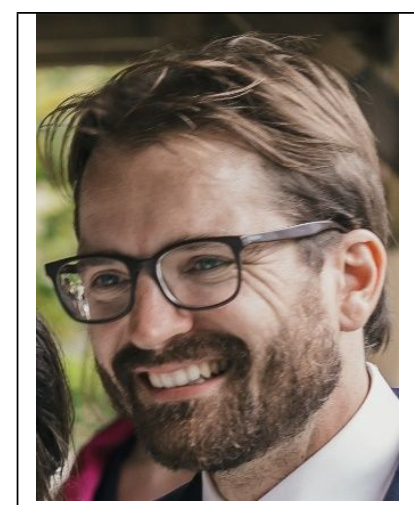

Dr. Andrea Schievano graduated (2006) in Environmental Engineering at University of Padua (Italy). He got his $\mathrm{PhD}$ (2010) in Agricultural ecology at University of Milan (Italy), focusing on environmental sustainability in food-production chains, towards circular-economy schemes. As Post-doctoral fellow, he worked on case studies at farm level, focusing on sustainable technologies and practices to mitigate environmental impacts of agricultural activities. From 2015, he has been principal investigator and lecturer at University of Milan, applying bioelectrochemistry to environmental biotechnologies, being the scientific director of a joint research center (e-BioCenter). He is also co-founder of a spin-off company that produces microalgae and develops innovative food products (spireat.it). Actually, he is part of the research team at the food security unit of the EU Commission - Joint Research Center (Ispra, Italy).

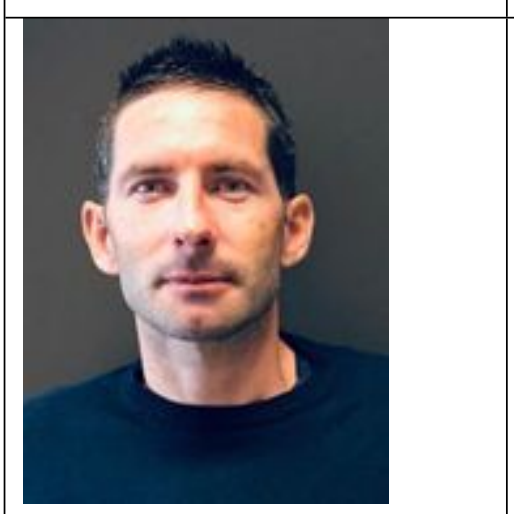

Dr. Raúl Berenguer is Senior Researcher at the Institute of Materials Science of the University of Alicante (Spain). He graduated in Chemistry (2004) and got his PhD in Materials Science and applied electrochemistry (2010) at this institution. As Post-Doct researcher, he also joined the Institute of Multidisciplinary Research for Advanced Materials at Tohoku University (Japan); the Chemical Engineering Department at the University of Málaga (Spain); and the IMDEA Water Institute (Spain). His research career has been mainly dedicated to the study and optimization of electrodes and electrochemical technologies for environmental applications, like wastewater treatment and energy storage/conversion. He has been recently awarded with a "Ramón y Cajal" contract by the Spanish State Research Agency and, among different interests, is focused on the study of electrode materials for microbial electrochemical technologies.

\begin{tabular}{|l} 
Andrea Goglio graduated in 2016 in Agricultural Science at the \\
University of Milan (Italy) with a research project at the China \\
Agricultural University of Beijing (China) on the renewable energy and \\
nutrients from organic waste by anaerobic digestion process. In the same \\
year, he received the professional license of Agronomist and in 2013 he \\
took the bachelor degree in Agricultural Science and Technology at the \\
University of Milan. Presently, he is a PhD student at the Department of \\
Agricultural and Environmental Sciences of the University of Milan. \\
During his research experience, he collaborated also with the University \\
of Alcalà de Henares (Spain), University of Alicante (Spain) and \\
presently he is PhD visiting student at the University of California - Davis \\
(USA). His research has been mainly dedicated to the wastewater \\
treatment focused on the nutrients recovery and the re-use of that as \\
fertilizers/conditioners in agricultural soil.
\end{tabular}

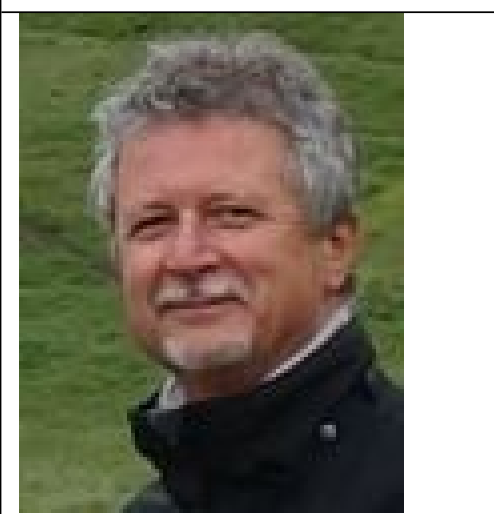

Prof. Stefano Bocchi, Ph.D in Crop Science, is now Full Professor of Agronomy and Cropping Systems. As Visiting Scientist at the Agronomy Department University of California, Davis (1985-86), at IRRIPhilippines (1992), and Wageningen University (1991), he developed research projects on cereals, forage crops, agro-food systems analysis and management. His work experience and responsibilities include: teaching of several graduate and undergraduate courses of agronomy, agroecology, agro-food systems, food shed management, landscape agronomy, tropical crops, organic farming; participating the scientific board of the Ph.D. program in agro-ecology; leading i) the "Geomatic Lab for Agriculture and Environment”, ii) CICSAA Inter-University Centre for International Cooperation for Agro-food systems development; iii) teams of research in several projects on farming system analysis and management, both at national and international level. Coordinator of 
GAIA 2050, Research Centre for the Health of the Planet. Member of some Boards of international Congress (TRC, ORP), Research Journals, Scientific Societies. Author of more than 180 scientific papers. He has been involved in several projects for international cooperation in Albania, Brasil, China, Ecuador, Egypt, Kenya, Lebanon, Peru, Philippines, Sierra Leon, Tanzania. He was the scientific curator of the Biodiversity Park in EXPO 2015. Presindent of Associazione Italiana di Agroecologia (AIDA).

Dr. Stefania Marzorati is currently a Post-Doc researcher at the Department of Environmental Sciences and Policy of the University of Milan.

She got her PhD degree in Chemical Sciences (2015) at University of Milan (Italy) with a thesis on nano- and micro-structured carbon materials for electrochemical oxygen reduction reaction. In the years of Post-doc research, her interests have been firstly devoted to preparation/characterization of carbon-based materials for microbial fuel cells application. At present her main research studies aim at valorizing agro-industrial wastes as sources of bioactive compounds. Her expertise lies in the isolation of added-value natural compounds through environmentally friendly techniques (i.e. supercritical $\mathrm{CO}_{2}$ extraction) and their characterization through chromatographic, electrochemical and physico-chemical methods.

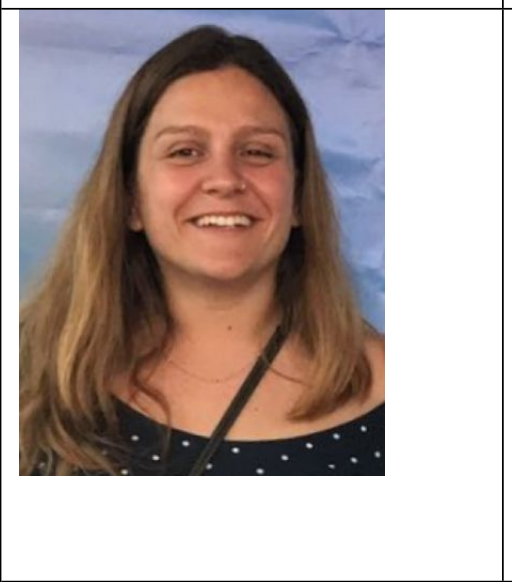

Dr. Laura Rago is currently a postdoctoral researcher at the Helmholtz Centre for Environmental Research - UFZ in Leipzig (Germany). In 2015, she obtained her $\mathrm{PhD}$ at Universitat Autònoma de Barcelona (Spain) receiving the Best PhD Thesis Award in Biotechnology. Her formation started from the medical biotechnology and nanotechnology, progressed to environmental microbiological approaches to treat dangerous gases, to arrive finally to the microbiological study of different BES inoculated with anaerobic pure and mixed cultures, which was also the focus of the PhD thesis. In the last years, her research has been conducted in collaboration with some of the leading international biotechnology research groups across the world (Italy, Spain, Portugal, USA among others) with diverse Microbial Electrochemical Technology (MET) expertise.

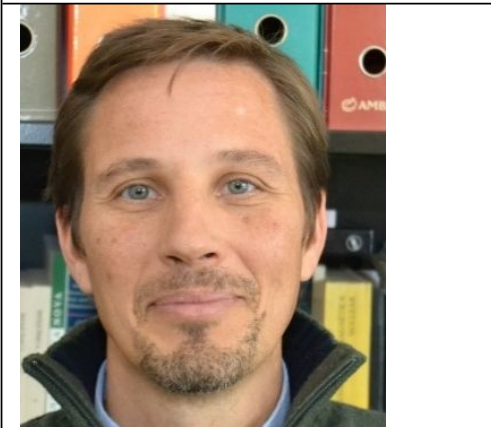

Dr. Ricardo Louro is a Researcher and Professor of Bioenergetics and Spectroscopy at Universidade Nova de Lisboa, Portugal. His research is focused on the characterization of the molecular mechanisms of extracellular electron transfer, which are key to the efficient operation of BioElectrochemical Systems. At the start of his career Dr. Louro was nominated a Burgen Scholar by the Academia Europaea and he pioneered the use of NMR, combined with electrochemistry and kinetics measurements, to disentangle redox properties of individual metal centers in multicenter proteins. The multicenter redox proteins seat at the core of bioenergetics and play key roles in the metabolism of all living organisms and are key players in the operation of BioElectrochemical Systems. Dr Louro has also organized or participated in the scientific committees of more than 10 international meetings, and chaired the organization of the latest general ISMET meeting of the International Society for Microbial Electrochemistry and Technology in Lisbon, Portugal. 


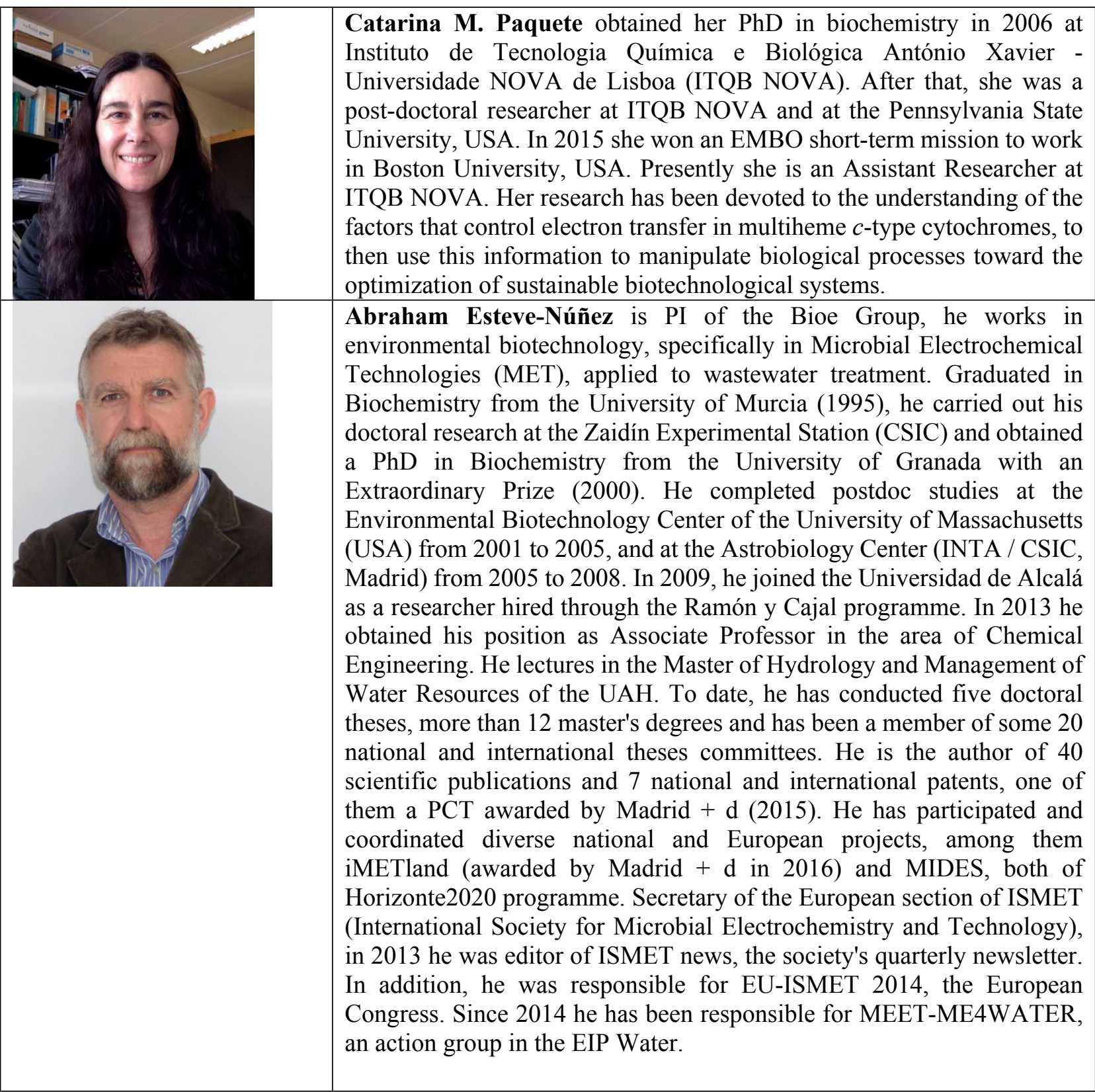




\section{Table of Content}
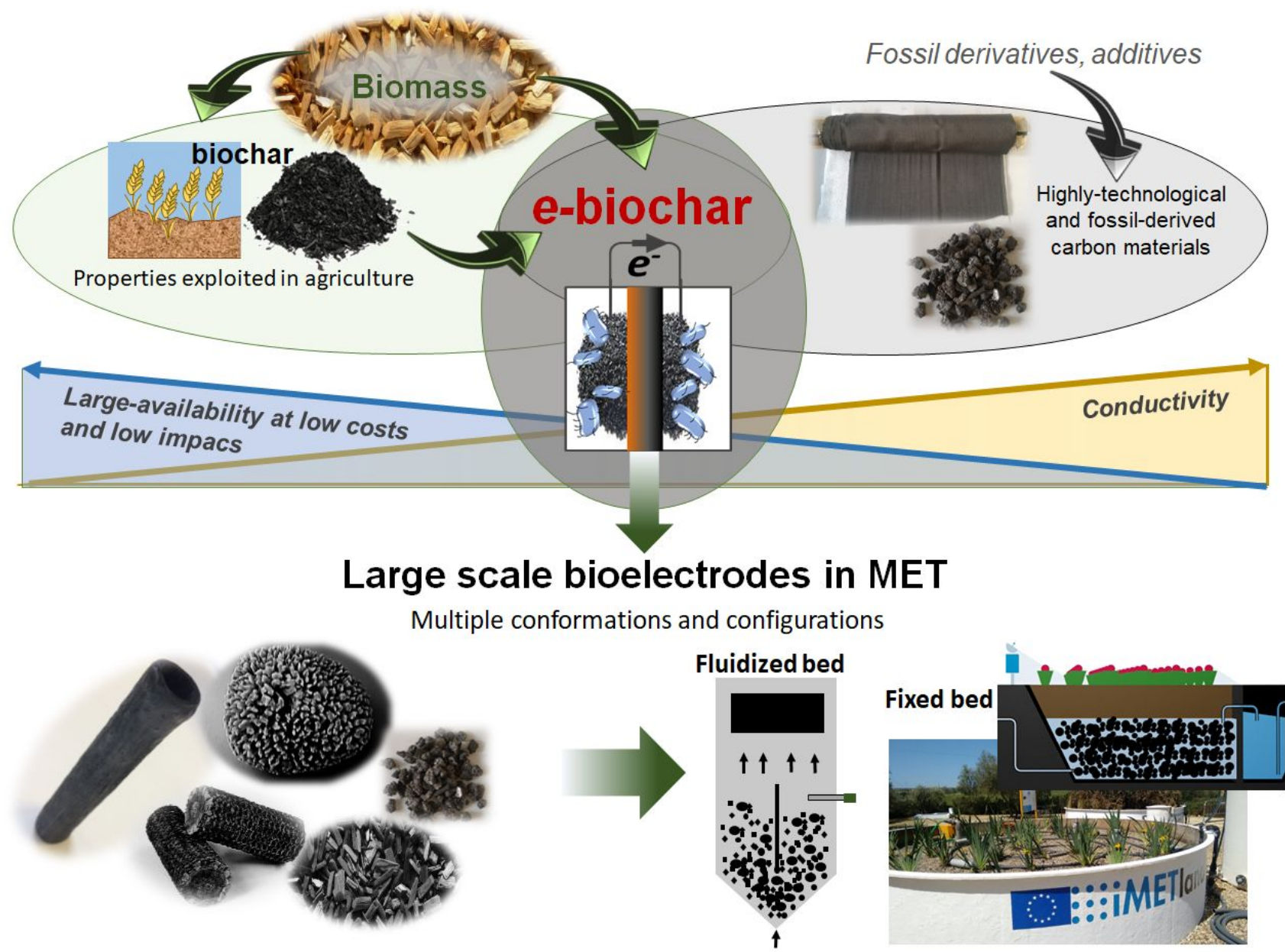

\section{Synopsis (For Table of Contents Use Only)}

Electroactive biochar (e-biochar) can be an ideal platform material to fabricate large-scale bioelectrodes for environmental applications of microbial electrochemical technologies. 


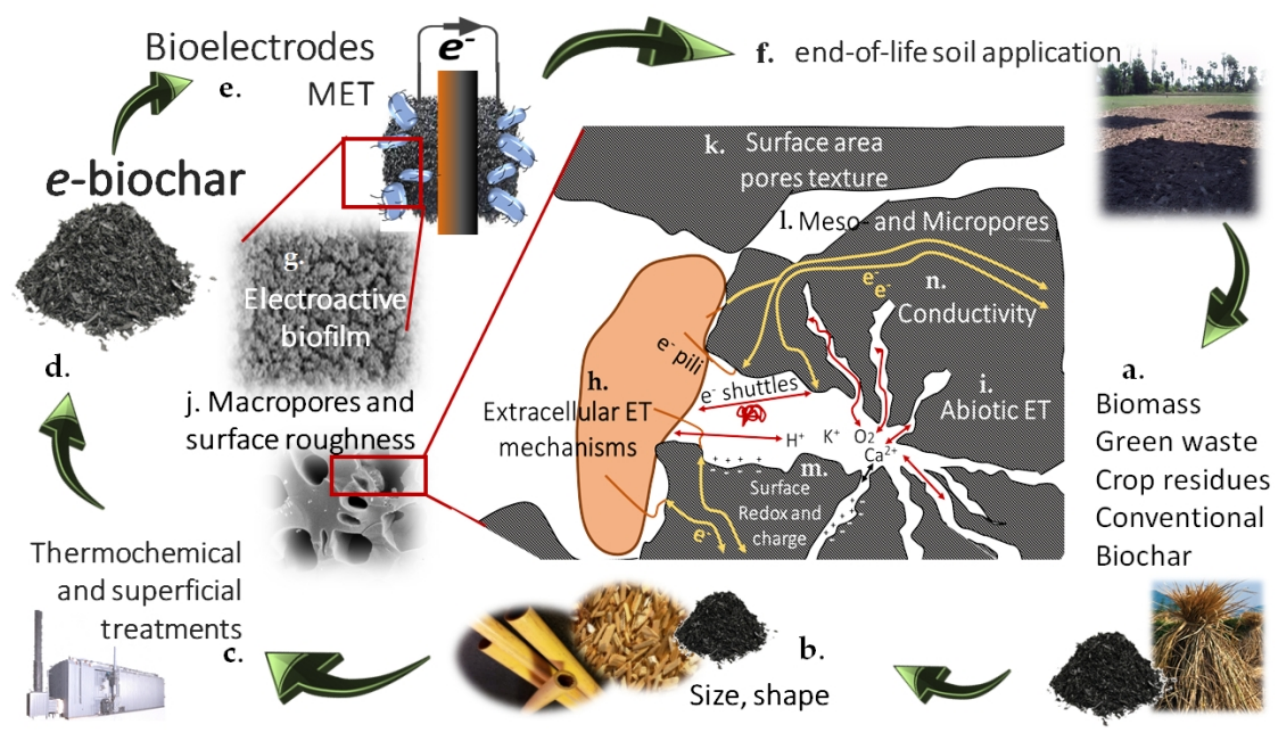

Figure 1 - Low-cost and widely available materials are needed for large-scale environmental applications of microbial electrochemical technologies (MET), when most high-tech materials are substantially excluded. Electroactive biochar (e-biochar) might open a new perspective. Residual biomass derived from agroforestry and conventional biochars (a) undergo: mechanical pretreatments to set precise conformations (b), optimized thermochemical conversions and specific superficial treatments (c), to sustainably produce electroactive-biochar (e-biochar) (d), as base for the fabrication of bioelectrodes in possible large-scale MET (e). At end-of-life, such electrodes can be used in soil conditioning and e-biochar might contribute to soil fertility (f). The word 'electroactive', under the point of view of MET, includes a series of chemical/textural/structural properties that tend to simultaneously optimize: electroactive biofilm growth $(\mathrm{g})$, microbial extracellular electron transfer (ET) mechanisms $(\mathrm{h})$ and abiotic reversible redox reactions towards ET (i), surface area and pores texture $(j)$, porosity distribution $(k, l)$, surface redox and charge properties (capacitance), due to chemical composition $(m)$ and sufficient electrical conductivity over given distances (n). 

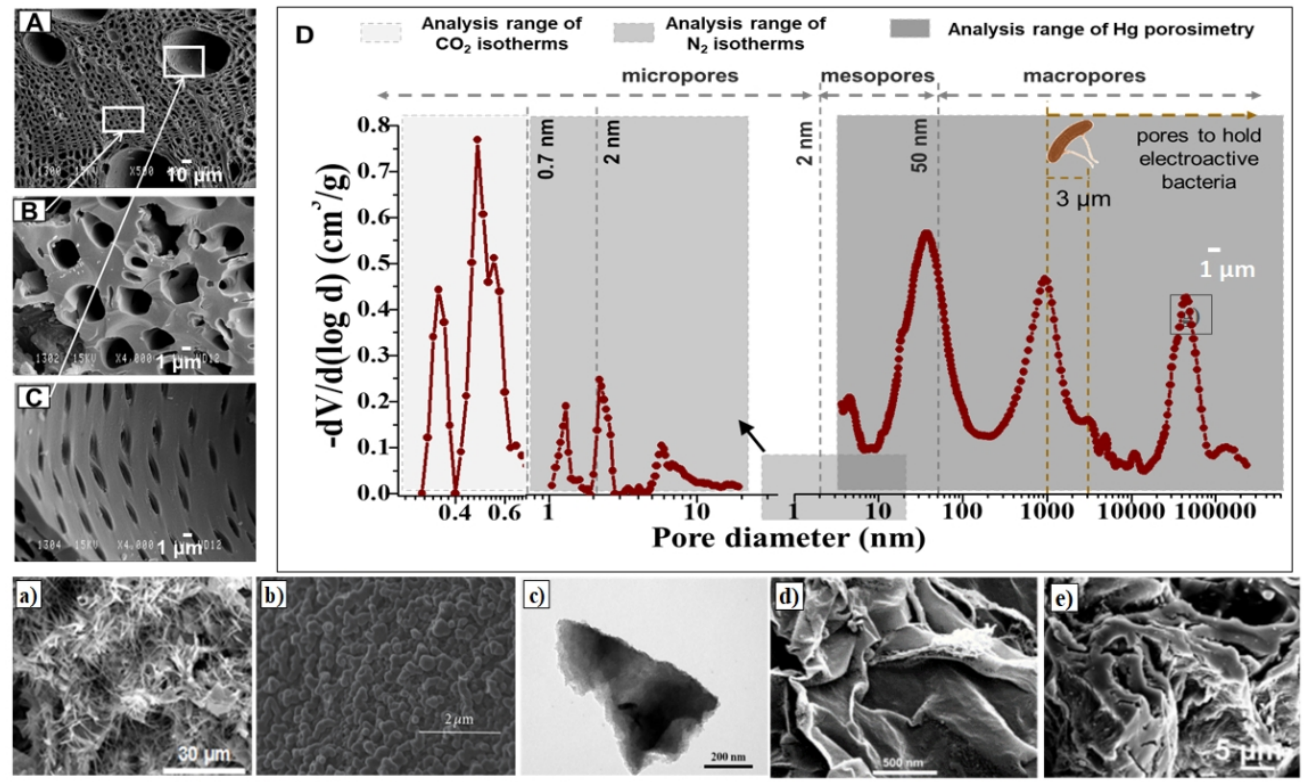

Figure 2 - Scanning electron microscopy (SEM) images of biochars synthesized by different groups in the literature: A-C) Prado et al., 2018 ; D) Pore size distributions from different techniques (considering DFT model and Washburn's equation for isotherms and porosimetry, respectively) of a quercus-derived biochar shown in A-C. Other SEM reports at different scales: a) Q. Chen et al., 2018; b) Lin et al., 2017; c) Ma et al., 2016; d) Yuan et al., 2014; e) Zha et al., 2016 (Chen et al. 2018; Lin et al. 2017; Ma et al. 2016; Yuan et al. 2014; Zha et al. 2016). SEM images demonstrating biochar-mediated interspecies electron transfer in f) G. metallireducens and G. sulfurreducens and g) G. metallireducens (rods) and M. barkeri (spheres) cocultures (Chen et al. 2014). Reprinted (adapted) with permission from (Chen et al. 2018; Lin et al. 2017; Ma et al. 2016; Yuan et al. 2014; Zha et al. 2016). Copyright (c) 2017, American Chemical Society and Elsevier.

$211 \times 129 \mathrm{~mm}(144 \times 144$ DPI $)$ 